\title{
Emissions of nitrogen oxides from US urban areas: estimation from Ozone Monitoring Instrument retrievals for 2005-2014
}

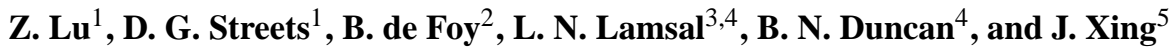 \\ ${ }^{1}$ Energy Systems Division, Argonne National Laboratory, Argonne, IL 60439, USA \\ ${ }^{2}$ Department of Earth and Atmospheric Sciences, Saint Louis University, St. Louis, MO 63108, USA \\ ${ }^{3}$ Goddard Earth Sciences Technology and Research, Universities Space Research Association, Columbia, \\ MD 21046, USA \\ ${ }^{4}$ NASA Goddard Space Flight Center, Greenbelt, MD 20771, USA \\ ${ }^{5}$ US Environmental Protection Agency, Research Triangle Park, NC 27711, USA \\ Correspondence to: Z. Lu (zlu@anl.gov)
}

Received: 25 March 2015 - Published in Atmos. Chem. Phys. Discuss.: 28 May 2015

Revised: 2 September 2015 - Accepted: 3 September 2015 - Published: 21 September 2015

\begin{abstract}
Satellite remote sensing of tropospheric nitrogen dioxide $\left(\mathrm{NO}_{2}\right)$ can provide valuable information for estimating surface nitrogen oxides $\left(\mathrm{NO}_{x}\right)$ emissions. Using an exponentially modified Gaussian (EMG) method and taking into account the effect of wind on observed $\mathrm{NO}_{2}$ distributions, we estimate 3-year moving-average emissions of summertime $\mathrm{NO}_{x}$ from 35 US (United States) urban areas directly from $\mathrm{NO}_{2}$ retrievals of the Ozone Monitoring Instrument (OMI) during 2005-2014. Following conclusions of previous studies that the EMG method provides robust and accurate emission estimates under strong-wind conditions, we derive topdown $\mathrm{NO}_{x}$ emissions from each urban area by applying the EMG method to OMI data with wind speeds greater than 3$5 \mathrm{~m} \mathrm{~s}^{-1}$. Meanwhile, we find that $\mathrm{OMI} \mathrm{NO}_{2}$ observations under weak-wind conditions (i.e., $<3 \mathrm{~m} \mathrm{~s}^{-1}$ ) are qualitatively better correlated to the surface $\mathrm{NO}_{x}$ source strength in comparison to all-wind OMI maps; therefore, we use them to calculate the satellite-observed $\mathrm{NO}_{2}$ burdens of urban areas and compare with $\mathrm{NO}_{x}$ emission estimates. The EMG results show that OMI-derived $\mathrm{NO}_{x}$ emissions are highly correlated $(R>0.93)$ with weak-wind $\mathrm{OMI} \mathrm{NO}_{2}$ burdens as well as with bottom-up $\mathrm{NO}_{x}$ emission estimates over 35 urban areas, implying a linear response of the OMI observations to surface emissions under weak-wind conditions. The simultaneous EMG-obtained effective $\mathrm{NO}_{2}$ lifetimes $(\sim 3.5 \pm 1.3 \mathrm{~h})$, however, are biased low in comparison to the summertime $\mathrm{NO}_{2}$ chemical lifetimes. In general, isolated urban areas with $\mathrm{NO}_{x}$ emission intensities greater than $\sim 2 \mathrm{Mg} \mathrm{h}^{-1}$ produce statis-
\end{abstract}

tically significant weak-wind signals in 3-year average OMI data. From 2005 to 2014, we estimate that total OMI-derived $\mathrm{NO}_{x}$ emissions over all selected US urban areas decreased by $49 \%$, consistent with reductions of $43,47,49$, and $44 \%$ in the total bottom-up $\mathrm{NO}_{x}$ emissions, the sum of weak-wind OMI $\mathrm{NO}_{2}$ columns, the total weak-wind $\mathrm{OMI} \mathrm{NO}_{2}$ burdens, and the averaged $\mathrm{NO}_{2}$ concentrations, respectively, reflecting the success of $\mathrm{NO}_{x}$ control programs for both mobile sources and power plants. The decrease rates of these $\mathrm{NO}_{x}$-related quantities are found to be faster (i.e., -6.8 to $-9.3 \% \mathrm{yr}^{-1}$ ) before 2010 and slower (i.e., -3.4 to $-4.9 \% \mathrm{yr}^{-1}$ ) after 2010. For individual urban areas, we calculate the $R$ values of pair-wise trends among the OMI-derived and bottomup $\mathrm{NO}_{x}$ emissions, the weak-wind $\mathrm{OMI} \mathrm{NO}_{2}$ burdens, and ground-based $\mathrm{NO}_{2}$ measurements, and high correlations are found for all urban areas (median $R=0.8$ ), particularly large ones ( $R$ up to 0.97 ). The results of the current work indicate that using the EMG method and considering the wind effect, the OMI data allow for the estimation of $\mathrm{NO}_{x}$ emissions from urban areas and the direct constraint of emission trends with reasonable accuracy.

\section{Introduction}

Nitrogen oxides $\left(\mathrm{NO}_{x}\right)$, the sum of nitrogen dioxide $\left(\mathrm{NO}_{2}\right)$ and nitric oxide (NO), is one of the six criteria pollutants identified by the US EPA (United States Environmental Pro- 
tection Agency) under the requirement of the Clean Air Act. $\mathrm{NO}_{x}$ plays a crucial role in tropospheric chemistry processes such as the formation of ground-level ozone and secondary inorganic and organic aerosols and, thus, it is also linked with other criterion pollutants including ozone, particulate matter, carbon monoxide, and sulfur oxides. Therefore, $\mathrm{NO}_{x}$ is not only harmful to human health but also implicated in a number of environmental problems, such as acid rain, smog, eutrophication, and climate change. $\mathrm{NO}_{x}$ emissions come from both anthropogenic (e.g., man-made combustion of fossil fuels, biofuel, and biomass) and natural sources (e.g., lightning, microbial processes in soils, and wildfires). Bottom-up inventories of $\mathrm{NO}_{x}$ emissions can be quite uncertain because the emission factors of anthropogenic sources strongly depend on the fuel type, technology, and combustion condition, while natural sources are inherently difficult to quantify.

Due to the strong absorption of $\mathrm{NO}_{2}$ molecules in the visible wavelength range of the spectrum, satellite instruments based on the principle of optical absorption spectroscopy serve as powerful tools to detect $\mathrm{NO}_{2}$ signals from space (Martin, 2008 and references therein). The short lifetime of $\mathrm{NO}_{x}$ in the atmosphere leads to a close correlation between observed $\mathrm{NO}_{2}$ columns and surface $\mathrm{NO}_{x}$ emission sources, implying the potential of space-borne instruments to aid in the estimation of $\mathrm{NO}_{x}$ emissions (Streets et al., 2013, 2014; and references therein). In the past 2 decades, satellite remote sensing of tropospheric $\mathrm{NO}_{2}$ columns has been widely and successfully used to map the spatial distributions of $\mathrm{NO}_{2}$ at local, regional, and global scales (e.g., Kim et al., 2009; Russell et al., 2010; Boersma et al., 2007, 2011; Martin et al., 2003), identify intensive point and area $\mathrm{NO}_{x}$ emission sources (e.g., Duncan et al., 2013; Kim et al., 2006; Lu and Streets, 2012; Streets et al., 2014; Wang et al., 2010; Zhang et al., 2009), and monitor diurnal/weekly/monthly/interannual variations of $\mathrm{NO}_{2}$ (e.g., Hilboll et al., 2013; Hudman et al., 2010; Richter et al., 2005; Russell et al., 2012; Schneider et al., 2015; Tong et al., 2015; van der A et al., 2008) for both anthropogenic and natural sources.

In general, local, regional, and global $\mathrm{NO}_{x}$ emissions can be verified, estimated, and optimized by using forward and inverse modeling of satellite $\mathrm{NO}_{2}$ columns (e.g., Boersma et al., 2005; Jaeglé et al., 2005; Kim et al., 2009; Martin et al., 2003; Wang et al., 2012). However, $\mathrm{NO}_{x}$ emissions and $\mathrm{NO}_{2}$ lifetimes can also be determined directly by analyzing the downwind patterns of the satellite-observed $\mathrm{NO}_{2}$ columns near the sources. Leue et al. (2001) used an exponential function to fit the downwind decay of GOME (Global Ozone Monitoring Experiment)-observed $\mathrm{NO}_{2}$ columns at the eastern shore of the US and estimated the $\mathrm{NO}_{2}$ lifetime by using the fitted $e$-folding distance and the averaged wind velocity. Kunhikrishnan et al. (2004) conducted a similar analysis over the Arabian Sea outflow region to estimate the regional $\mathrm{NO}_{x}$ lifetime for the Indian subcontinent. This method was revised by Beirle et al. (2004), who fitted the GOME-observed $\mathrm{NO}_{2}$ columns across the shipping lane between Sri Lanka and
Indonesia with an exponentially modified Gaussian (EMG) function and derived the mean $\mathrm{NO}_{x}$ lifetime and the corresponding ship emissions for 1996-2001. Hereinafter, we call this approach the EMG method. By fitting the downwind line densities of the OMI (Ozone Monitoring Instrument)observed $\mathrm{NO}_{2}$ separately for eight wind directions, Beirle et al. (2011) further improved the EMG method and determined the average $\mathrm{NO}_{x}$ emissions and lifetimes simultaneously for nine worldwide megacities during 2005-2009. Using a similar method, Ialongo et al. (2014) estimated the average summertime $\mathrm{NO}_{x}$ emissions and lifetimes of three cities in the Baltic Sea region during 2005-2011. The EMG method and its variant versions have also been applied to the satellite observations of $\mathrm{SO}_{2}$ to constrain $\mathrm{SO}_{2}$ lifetimes and emissions from volcanoes (Beirle et al., 2014; Krotkov et al., 2010; Theys et al., 2013; Carn et al., 2013) and large anthropogenic point sources (Fioletov et al., 2015).

Recently, several studies discussed the applicability and reliability of the EMG method. Valin et al. (2013) suggested that the $\mathrm{NO}_{x}$ emissions and chemical lifetimes would be better quantified when winds are fast because the downwind $\mathrm{NO}_{2}$ decay under this condition is dominated by chemical removal, not variability of the winds. Introducing the plume rotation technique, they inferred $\mathrm{NO}_{x}$ emissions of Riyadh from the OMI measurements with fast winds $\left(>6.4 \mathrm{~m} \mathrm{~s}^{-1}\right)$ only and derived $\mathrm{NO}_{x}$ chemical lifetimes in slower wind conditions with the mass balance method. Additionally, de Foy et al. (2014) evaluated the performance of the EMG method using simulated column densities over a point source with known emissions under three chemical lifetime cases. They found that the EMG method generally provided reliable emission estimates at fast-wind-speed conditions ( $>3 \mathrm{~m} \mathrm{~s}^{-1}$ ); however, the lifetime estimates were biased low and quite sensitive to the selection of the wind-speed cutoff and the accuracy of the plume rotation. This implies that, in practice, the EMG-derived lifetimes should not be treated as chemical lifetimes but rather as "effective lifetimes" that include the influences of chemical conversion, plume meandering, grid resolution, sampling issues, etc. (see also Fioletov et al., 2015; Ialongo et al., 2014). Nevertheless, the EMG method can provide quite accurate emission estimates if the issues of wind speed and direction are appropriately treated.

In this study, we use OMI $\mathrm{NO}_{2}$ retrievals and an EMG method to estimate $\mathrm{NO}_{x}$ emissions from 35 major US urban areas during the OMI era of 2005-2014. Although there have been a number of studies reporting satellite observations of $\mathrm{NO}_{2}$ over some US cities, they mainly focused on the interannual trends and/or monthly/weekly variations of the satellite signals themselves (van der A et al., 2008; Hilboll et al., 2013; Schneider et al., 2015; Russell et al., 2012; Kim et al., 2009) or the comparison of satellite observations with pre-existing emissions and/or surface measurement data sets (Tong et al., 2015; Lamsal et al., 2015). In this study, we use the EMG method to estimate $\mathrm{NO}_{x}$ emissions of nearly all major US cities directly from satellite $\mathrm{NO}_{2}$ observations and 
without using a chemical transport model. The prime motivation of this work is not to demonstrate the well-known dramatic decrease of urban $\mathrm{NO}_{2}$ across the country (although we do have new findings by taking into account the wind effect) but to show the capability of the EMG method to provide direct and reliable estimates of urban $\mathrm{NO}_{x}$ emissions. The current work also differs from previous EMG-related studies (Beirle et al., 2004, 2011; de Foy et al., 2014, 2015; Ialongo et al., 2014; Valin et al., 2013), all of which used a multi-annual averaged satellite $\mathrm{NO}_{2}$ map in the EMG fit and thus only obtained a long-term averaged emission estimate. This work, to our knowledge, is the first study to show that the EMG method can also provide estimates of emission trends with reasonable accuracy. The rest of the paper is organized as follows: Sect. 2 documents the methodology and data sets; Sect. 3 highlights the effect of wind on the OMI $\mathrm{NO}_{2}$ observations (Sect. 3.1), presents the relationship between the EMG-derived $\mathrm{NO}_{x}$ emissions and the OMI $\mathrm{NO}_{2}$ observations (Sect. 3.2), and compares the trends of various $\mathrm{NO}_{x}$-related quantities (Sect. 3.3); and Sect. 4 summarizes the major findings of this work.

\section{Data and methodology}

\section{1 $\mathrm{OMI} \mathrm{NO}_{2}$ retrievals and processing}

The OMI is an ultraviolet/visible nadir spectrometer onboard the National Aeronautics and Space Administration (NASA) Aura satellite, which was launched in a sun-synchronous ascending orbit at $705 \mathrm{~km}$ altitude in July 2004 (Levelt et al., 2006). It measures solar irradiance and earthshine radiance in the wavelength range of $270-500 \mathrm{~nm}$ and has been continuously providing aerosol and gaseous (including $\mathrm{NO}_{2}$ ) column observations at approximately 13:45 local Equatorcrossing time (LT) with nearly daily global coverage in the past decade. In this work, we use the version 2.0 product of the Dutch OMI NO 2 (DOMINO) tropospheric vertical column densities (TVCDs) developed at the Royal Netherlands Meteorological Institute (KNMI) for the years from 2005 to 2014 (Boersma et al., 2007, 2011). This version of the product uses an improved OMI $\mathrm{NO}_{2}$ retrieval algorithm on the basis of better air mass factors, an a posteriori correction for across-track stripes, and high-resolution input profiles of the terrain height and the surface albedo climatology, and has been reported to be in better agreement with independent measurements and model simulations in comparison to the previous version (Boersma et al., 2011).

To increase the amount of valid OMI data, the filter criteria of the level-2 swath data were relaxed somewhat. We removed the daily pixel retrievals with solar zenith angle $>80^{\circ}$, cloud radiance fraction $>0.5$, or surface albedo $>0.3$. The largest five pixels at the swath edges (i.e., rows 1-5 and rows 56-60) were excluded to limit the across-track pixel width to $<70 \mathrm{~km}$. Since June 2007, some row anomalies (RAs) have developed on the OMI detectors and affected the data quality of a number of cross-track scenes (http://www.knmi. nl/omi/research/product/rowanomaly-background.php). The RAs change over time and we therefore dynamically removed the affected pixels based on the RA flags in the DOMINO product. We only used the summer half-year data (i.e., April-September) because the short $\mathrm{NO}_{x}$ lifetime in this period makes the relationship between $\mathrm{NO}_{x}$ emissions and satellite $\mathrm{NO}_{2}$ observations more direct than in other months (e.g., Russell et al., 2012; Wang et al., 2012; Lu and Streets, 2012). For the $\mathrm{OMI} \mathrm{NO}_{2}$ maps of the entire domain of the continental US (e.g., Fig. 1a), all valid pixels were oversampled on a $2 \mathrm{~km} \times 2 \mathrm{~km}$ grid to obtain detailed spatial distributions of $\mathrm{NO}_{2}$ over hotspots ( $\mathrm{Lu}$ et al., 2013; Russell et al., 2010; Fioletov et al., 2011, 2013; de Foy et al., 2009).

\subsection{Selection of urban areas}

Table 1 lists and Fig. 1a shows the locations of the urban areas selected in this work. We examined the top 50 urban areas in the US based on population size and the observed satellite $\mathrm{NO}_{2}$ signals (Fig. 1a). We combined adjacent urban areas that are so close as to share the same $\mathrm{NO}_{2}$ hotspot (e.g., Washington, DC, and Baltimore; and Los Angeles and Riverside) and omitted some urban areas where the $\mathrm{NO}_{2}$ signals are not isolated due to the influence of large $\mathrm{NO}_{x}$ emitting sources nearby (e.g., Pittsburgh, Milwaukee, San Francisco). In total, 35 urban areas were selected for analysis and together they accounted for $\sim 23 \%$ of total $\mathrm{NO}_{x}$ emissions and $\sim 50 \%$ of the total urban population in the US during the period 2005-2014.

\subsection{Wind fields}

Wind information (including speed and direction) is crucial in exploring its influence on the $\mathrm{OMI} \mathrm{NO}_{2}$ observations and estimating the $\mathrm{NO}_{x}$ emissions with the EMG method described in Sect. 2.4. In this work, we use the gridded wind field data sets of the ERA-interim reanalysis at the resolution of $0.5^{\circ} \times 0.5^{\circ}$ developed by the European Centre for Medium-range Weather Forecast (ECMWF; Dee et al., 2011). The ERA-interim reanalysis provides global wind fields for 60 vertical levels at four time steps per day (i.e., 00:00, 06:00, 12:00, 18:00 UTC) from 1979 to present on the N128 reduced Gaussian grid. Valin et al. (2013) expected that the EMG results would be insensitive to the choice of wind field data sets. This was confirmed by de Foy et al. (2015), who tested wind fields of both the ERA-interim reanalysis and the North American Regional Reanalysis (NARR) and obtained similar results in the EMG analysis. The $\mathrm{NO}_{x}$ emitted near the surface of the urban areas can undergo rapid vertical mixing, and we thus use the averaged wind fields of the bottom eight levels (i.e., from the surface to $\sim 500 \mathrm{~m}$ ), similar to the treatment of Beirle et al. (2011). We assume that the daily $\mathrm{OMI} \mathrm{NO}_{2}$ spatial pattern of a hotspot should not reflect 
Table 1. Summary of the average bottom-up $\mathrm{NO}_{x}$ emissions, OMI-derived $\mathrm{NO}_{x}$ results, ground-based $\mathrm{NO}_{2}$ measurements, and their linear trends for 35 US urban areas during the summer half-year (April-September) from 2006* to 2013*a.

\begin{tabular}{|c|c|c|c|c|c|c|c|c|c|c|c|c|c|}
\hline \multirow[b]{2}{*}{ Urban areas } & \multirow[b]{2}{*}{ Latitude } & \multirow[b]{2}{*}{ Longitude } & \multirow{2}{*}{$\begin{array}{r}\text { NEI emissions } \\
2005-2014 \\
\left(\mathrm{Mg} \mathrm{h}^{-1}\right)\end{array}$} & \multicolumn{3}{|c|}{ Results at high wind speeds (WS) } & \multicolumn{2}{|c|}{ Results at low WS } & \multicolumn{4}{|c|}{ Linear trends from $2006^{*}$ to $2013^{*}\left(\% \mathrm{yr}^{-1}\right)$} & \multirow[b]{2}{*}{$\begin{array}{r}\text { Mean } \\
R^{\mathrm{b}}\end{array}$} \\
\hline & & & & $\begin{array}{r}\text { Mean WS } \\
\left(\mathrm{m} \mathrm{s}^{-1}\right)\end{array}$ & $\begin{array}{r}\text { OMI-derived } \\
\text { emissions }\left(\mathrm{Mg} \mathrm{h}^{-1}\right)\end{array}$ & $\begin{array}{r}\text { Effective } \\
\text { lifetime (h) }\end{array}$ & $\begin{array}{r}\text { Mean WS } \\
\left(\mathrm{m} \mathrm{s}^{-1}\right)\end{array}$ & $\begin{array}{r}\text { OMI burden } \\
(\mathrm{Mg})\end{array}$ & $\begin{array}{r}\text { NEI } \\
\text { emissions }\end{array}$ & $\begin{array}{r}\text { OMI-derived } \\
\text { emissions }\end{array}$ & $\begin{array}{r}\text { OMI burden } \\
\text { at } \mathrm{WS}<3 \mathrm{~m} \mathrm{~s}^{-1}\end{array}$ & $\mathrm{AQS}$ & \\
\hline Atlanta, GA & 33.74 & -84.32 & 12.7 & 5.7 & $6.7 \pm 2.8$ & $4.3 \pm 1.4$ & 1.9 & $25.0 \pm 10.1$ & -7.9 & $-7.8 \pm 3.3$ & $-15.3 \pm 6.2$ & -5.0 & 0.80 \\
\hline Boston, MA & 42.38 & -71.02 & 10.3 & 6.1 & $10.9 \pm 4.5$ & $5.3 \pm 1.7$ & 1.9 & $29.5 \pm 11.9$ & -6.1 & $-13.4 \pm 5.6$ & $-8.1 \pm 3.3$ & -4.7 & 0.84 \\
\hline Charlotte, NC & 35.34 & -80.86 & 3.3 & 5.8 & $2.7 \pm 1.1$ & $4.0 \pm 1.3$ & 1.8 & $8.7 \pm 3.5$ & -1.3 & $-7.9 \pm 3.4$ & $-12.9 \pm 5.2$ & -6.1 & 0.54 \\
\hline Chicago, IL & 41.78 & -87.68 & 30.7 & 7.4 & $23.3 \pm 9.7$ & $6.1 \pm 1.9$ & 2.1 & $86.3 \pm 34.8$ & -6.6 & $-7.8 \pm 3.3$ & $-5.7 \pm 2.3$ & -6.8 & 0.95 \\
\hline Cincinnati, $\mathrm{OH}$ & 39.12 & -84.50 & 7.9 & 4.9 & $4.9 \pm 2.0$ & $5.6 \pm 1.8$ & 1.8 & $16.9 \pm 6.8$ & -3.9 & $-8.5 \pm 3.6$ & $-6.0 \pm 2.5$ & -6.0 & 0.73 \\
\hline Dallas, TX & 32.86 & -96.96 & 14.8 & 7.4 & $8.1 \pm 3.4$ & $3.3 \pm 1.1$ & 2.0 & $26.8 \pm 10.8$ & -7.4 & $-12.2 \pm 5.1$ & $-5.3 \pm 2.1$ & -7.3 & 0.86 \\
\hline Denver, CO & 39.78 & -105.04 & 10.0 & 6.0 & $12.1 \pm 5.0$ & $3.5 \pm 1.1$ & 1.8 & $21.7 \pm 8.8$ & -2.4 & $-9.8 \pm 4.1$ & $-9.4 \pm 3.8$ & -2.1 & 0.78 \\
\hline Detroit, MI & 42.26 & -83.12 & 26.1 & 6.4 & $18.7 \pm 7.8$ & $5.2 \pm 1.7$ & 2.0 & $57.7 \pm 23.3$ & -6.6 & $-3.4 \pm 1.5$ & $-5.8 \pm 2.3$ & -5.3 & 0.76 \\
\hline El Paso, TX & 31.74 & -106.38 & 2.2 & 6.7 & $3.2 \pm 1.3$ & $3.0 \pm 0.9$ & 1.9 & $7.2 \pm 2.9$ & -3.3 & $-3.7 \pm 1.6$ & $-4.4 \pm 1.8$ & -4.6 & 0.77 \\
\hline Houston, TX & 29.82 & -95.28 & 13.5 & 5.9 & $11.3 \pm 4.7$ & $4.1 \pm 1.3$ & 1.9 & $30.3 \pm 12.2$ & -7.9 & $-5.2 \pm 2.3$ & $-5.1 \pm 2.1$ & -4.8 & 0.79 \\
\hline Indianapolis, IN & 39.80 & -86.12 & 4.3 & 5.6 & $3.1 \pm 1.3$ & $4.2 \pm 1.3$ & 2.0 & $8.5 \pm 3.4$ & -3.2 & $-5.7 \pm 2.5$ & $-6.5 \pm 2.6$ & -7.8 & 0.86 \\
\hline Jacksonville, FL & 30.40 & -81.60 & 5.2 & 5.7 & $4.7 \pm 2.0$ & $2.5 \pm 0.8$ & 1.9 & $9.9 \pm 4.0$ & -9.5 & $-6.3 \pm 2.8$ & $-9.5 \pm 3.8$ & -2.9 & 0.80 \\
\hline Kansas City, MO & 39.10 & -94.56 & 10.2 & 6.6 & $5.1 \pm 2.1$ & $3.9 \pm 1.2$ & 1.9 & $14.3 \pm 5.8$ & -4.4 & $-7.8 \pm 3.3$ & $-13.4 \pm 5.4$ & -4.9 & 0.86 \\
\hline Las Vegas, NV & 36.18 & -115.14 & 6.1 & 6.4 & $6.7 \pm 2.8$ & $2.0 \pm 0.7$ & 1.9 & $11.2 \pm 4.5$ & -3.3 & $-10.3 \pm 4.4$ & $-12.3 \pm 5.0$ & -3.0 & 0.60 \\
\hline Los Angeles, CA & 34.06 & -117.92 & 40.1 & 3.7 & $40.0 \pm 16.6$ & $3.6 \pm 1.2$ & 2.0 & $124.4 \pm 50.2$ & -10.7 & $-7.0 \pm 2.9$ & $-8.5 \pm 3.4$ & -7.6 & 0.97 \\
\hline Louisville, KY & 38.20 & -85.74 & 6.3 & 5.6 & $2.5 \pm 1.0$ & $3.5 \pm 1.1$ & 1.9 & $8.1 \pm 3.3$ & -7.6 & $-9.0 \pm 3.8$ & $-11.3 \pm 4.6$ & -13.1 & 0.70 \\
\hline Memphis, TN & 35.10 & -90.04 & 4.4 & 5.9 & $1.5 \pm 0.6$ & $3.2 \pm 1.0$ & 1.9 & $3.4 \pm 1.4$ & -7.3 & $-25.9 \pm 10.8$ & $-10.2 \pm 4.1$ & -2.7 & 0.83 \\
\hline Miami, FL & 26.02 & -80.34 & 13.4 & 5.4 & $5.6 \pm 2.3$ & $5.0 \pm 1.6$ & 1.9 & $28.7 \pm 11.6$ & -6.5 & $-10.2 \pm 4.3$ & $-4.5 \pm 1.8$ & -9.3 & 0.80 \\
\hline Minneapolis, MN & 44.96 & -93.22 & 12.8 & 6.9 & $9.3 \pm 3.9$ & $2.7 \pm 0.9$ & 2.0 & $25.9 \pm 10.5$ & -8.6 & $-12.4 \pm 5.2$ & $-11.3 \pm 4.6$ & -11.0 & 0.89 \\
\hline Nashville, TN & 36.14 & -86.62 & 2.9 & 5.6 & $2.0 \pm 0.8$ & $2.8 \pm 0.9$ & 1.8 & $4.0 \pm 1.6$ & -4.4 & $-13.8 \pm 5.8$ & $-14.9 \pm 6.0$ & -6.9 & 0.78 \\
\hline New Orleans, LA & 29.98 & -90.22 & 7.2 & 5.3 & $3.6 \pm 1.5$ & $3.2 \pm 1.0$ & 1.8 & $6.0 \pm 2.5$ & -5.2 & $-7.3 \pm 3.2$ & $-1.8 \pm 1.1$ & -5.4 & 0.48 \\
\hline New York, NY & 40.72 & -73.80 & 43.2 & 5.3 & $50.7 \pm 21.1$ & $3.1 \pm 1.0$ & 1.9 & $128.1 \pm 51.7$ & -6.3 & $-5.9 \pm 2.5$ & $-6.8 \pm 2.8$ & -6.7 & 0.96 \\
\hline Philadelphia, PA & 39.98 & -75.16 & 17.8 & 5.2 & $23.3 \pm 9.8$ & $3.2 \pm 1.0$ & 1.9 & $53.0 \pm 21.4$ & -7.2 & $-9.1 \pm 4.0$ & $-18.1 \pm 7.3$ & -7.2 & 0.93 \\
\hline Phoenix, AZ & 33.54 & -112.00 & 10.8 & 5.4 & $12.2 \pm 5.1$ & $1.8 \pm 0.6$ & 1.7 & $21.1 \pm 8.5$ & -4.7 & $-13.0 \pm 5.5$ & $-6.4 \pm 2.6$ & -4.6 & 0.80 \\
\hline Portland, OR & 45.44 & -122.60 & 6.9 & 3.9 & $9.9 \pm 4.1$ & $1.2 \pm 0.4$ & 2.1 & $15.8 \pm 6.4$ & -3.8 & $-5.0 \pm 2.2$ & $-11.6 \pm 4.7$ & -8.1 & 0.91 \\
\hline Richmond, VA & 37.42 & -77.30 & 3.6 & 4.9 & $1.8 \pm 0.7$ & $3.5 \pm 1.1$ & 2.0 & $5.1 \pm 2.1$ & -7.8 & $-5.7 \pm 2.7$ & $-14.7 \pm 5.9$ & -9.4 & 0.68 \\
\hline Salt Lake City, UT & 40.72 & -111.92 & 3.6 & 4.8 & $8.2 \pm 3.5$ & $1.3 \pm 0.4$ & 1.8 & $14.3 \pm 5.8$ & -3.7 & $-12.1 \pm 5.4$ & $-9.3 \pm 3.8$ & -10.8 & 0.89 \\
\hline San Antonio, TX & 29.56 & -98.44 & 5.4 & 5.7 & $3.2 \pm 1.4$ & $2.1 \pm 0.7$ & 2.0 & $7.9 \pm 3.2$ & -5.7 & $-10.2 \pm 4.4$ & $-8.2 \pm 3.4$ & -1.6 & 0.75 \\
\hline San Diego, CA & 32.66 & -116.86 & 6.0 & 4.0 & $8.8 \pm 3.7$ & $3.1 \pm 1.0$ & 2.0 & $21.7 \pm 8.8$ & -9.8 & $-6.3 \pm 3.0$ & $-4.2 \pm 1.7$ & -7.8 & 0.91 \\
\hline Seattle, WA & 47.42 & -122.22 & 13.0 & 3.7 & $13.3 \pm 5.7$ & $3.4 \pm 1.1$ & 2.0 & $30.0 \pm 12.1$ & -4.8 & $-6.5 \pm 3.3$ & $-4.3 \pm 1.9$ & -5.6 & 0.80 \\
\hline St. Louis, MO & 38.64 & -90.32 & 11.0 & 5.2 & $4.9 \pm 2.0$ & $6.8 \pm 2.1$ & 1.9 & $15.8 \pm 6.4$ & -0.7 & $-10.9 \pm 4.5$ & $-8.9 \pm 3.6$ & -10.0 & 0.59 \\
\hline Tampa, FL & 27.90 & -82.42 & 8.5 & 5.6 & $6.9 \pm 2.9$ & $2.7 \pm 0.9$ & 1.8 & $14.3 \pm 5.8$ & -9.5 & $-6.6 \pm 2.8$ & $-9.1 \pm 3.7$ & -10.5 & 0.80 \\
\hline Tucson, AZ & 32.24 & -110.88 & 3.1 & 5.9 & $1.5 \pm 0.6$ & $3.6 \pm 1.2$ & 1.8 & $3.9 \pm 1.6$ & -6.0 & $-6.2 \pm 2.7$ & $-4.0 \pm 1.7$ & -7.4 & 0.59 \\
\hline Virginia Beach, VA & 36.90 & -76.32 & 6.1 & 6.2 & $4.6 \pm 1.9$ & $1.4 \pm 0.4$ & 2.0 & $7.3 \pm 2.9$ & -8.7 & $-8.9 \pm 3.7$ & $-8.7 \pm 3.5$ & -6.1 & 0.79 \\
\hline Washington, DC & 39.20 & -76.58 & 18.5 & 5.0 & $13.0 \pm 5.5$ & $4.7 \pm 1.5$ & 1.9 & $48.5 \pm 19.6$ & -7.3 & $-10.2 \pm 4.3$ & $-6.9 \pm 2.8$ & -6.2 & 0.92 \\
\hline
\end{tabular}

the wind strength and direction at the OMI overpass time of $\sim$ 13:45 LT but the average wind fields a few hours before the satellite takes the measurement. For simplicity, we choose 12:00 LT as the time of the wind fields. The reasons are as follows: first, the choice of 12:00 LT of the ERA-interim reanalysis data set has been proven to reproduce the observed spatial transport pattern of the $\mathrm{OMI} \mathrm{NO}_{2}$ successfully at the daily level (Valin et al., 2013); second, if the average wind over the last $6 \mathrm{~h}$ is considered, the results have been reported to change only $\sim 10 \%$ (Beirle et al., 2011). Consequently, daily wind speed and wind direction maps over the entire domain of the US were interpolated temporally at 12:00 LT and spatially on a $2 \mathrm{~km} \times 2 \mathrm{~km}$ grid in association with the oversampled $\mathrm{OMI} \mathrm{NO}_{2}$ maps.

\subsection{Exponentially modified Gaussian method}

Beirle et al. (2011) presented a method using an EMG function to fit the downwind patterns of $\mathrm{OMI} \mathrm{NO}_{2}$ line densities separately for eight wind directions and simultaneously determined the $\mathrm{NO}_{x}$ emissions and lifetimes for nine megacities around the world. In this work, we follow a similar methodology but with a number of enhancements. For each urban area, we did not separate the OMI $\mathrm{NO}_{2}$ measurements into different wind directions but rotated and overlapped the daily $\mathrm{OMI} \mathrm{NO}_{2}$ maps in the range of $300 \mathrm{~km}$ around the urban center (see Table 1 for the latitudes and longitudes) to align all the wind directions at the urban center in the $x$ direction (Valin et al., 2013; de Foy et al., 2014, 2015). This process increases the number of OMI samples, potentially increases the signal-to-noise ratio, and benefits the trend analysis using the EMG method. The wind-aligned $\mathrm{OMI} \mathrm{NO}_{2}$ maps were further reduced to one-dimensional line densities by integrating the $\mathrm{NO}_{2}$ data in the acrosswind direction over a maximum interval of $\pm 120 \mathrm{~km}$ (e.g., Chicago in Fig. 2). Depending on the size of the urban areas, smaller across-wind integration intervals down to $\pm 60 \mathrm{~km}$ were chosen for smaller $\mathrm{NO}_{2}$ hotspots to minimize interference from background $\mathrm{NO}_{2}$ and neighboring $\mathrm{NO}_{x}$ sources. The EMG model proposed by Beirle et al. (2011) was then used to fit the $\mathrm{NO}_{2}$ line densities. As a function of the distance from the urban center $x$, the EMG model is expressed 

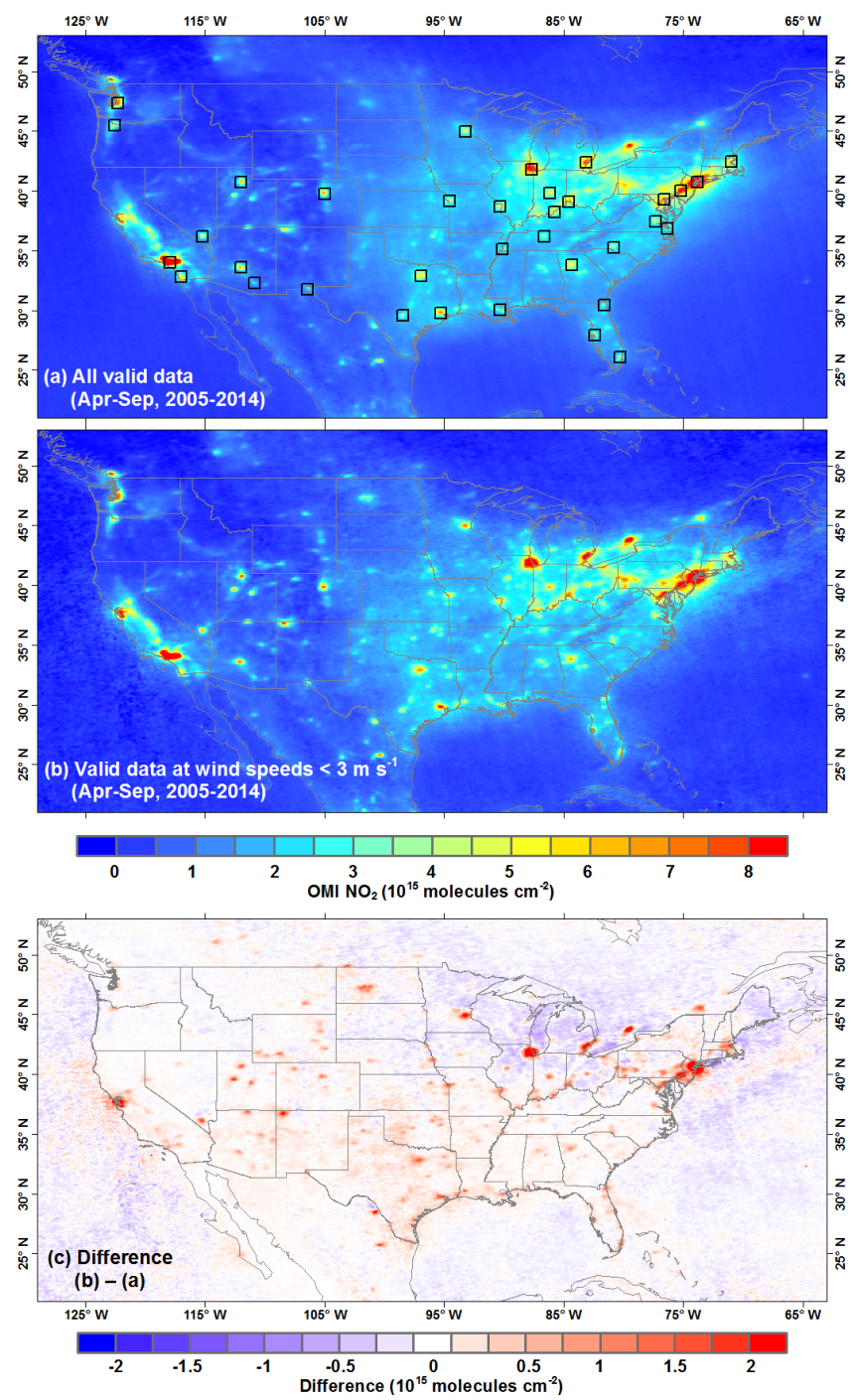

Figure 1. Average summer half-year (i.e., April-September) OMI $\mathrm{NO}_{2}$ TVCDs over the continental US during 2005-2014: (a) all valid data were used, (b) only valid data with wind speeds $<3 \mathrm{~m} \mathrm{~s}^{-1}$ were used, and (c) the difference between (b) and (a). Squares in (a) indicate the urban areas selected in this work.

as Eqs. (1)-(3):

$\mathrm{OMI}_{\mathrm{NO}_{2}, \text { line }}\left(x \mid \mu, \sigma, x_{0}, \alpha, B\right)=\alpha \cdot f\left(x \mid \mu, \sigma, x_{0}\right)+B$

$=\alpha \cdot\left[e\left(x \mid x_{0}, \mu\right) \otimes G(x \mid \sigma)\right]+B$

$e\left(x \mid x_{0}, \mu\right)=\exp \left(-\frac{x-\mu}{x_{0}}\right)$ for $x \geq \mu$,

otherwise $e\left(x \mid x_{0}, \mu\right)=0$,

$G(x \mid \sigma)=\frac{1}{\sqrt{2 \pi} \sigma} \exp \left(-\frac{x^{2}}{2 \sigma^{2}}\right)$.

The estimation problem is nonlinear with five parameters to be determined (i.e., $\mu, \sigma, x_{0}, \alpha$, and $B$ ). Mathematically, Eqs. (1)-(3) can be written as (Kalambet et al., 2011, and references therein)

$\mathrm{OMI}_{\mathrm{NO}_{2}, \text { line }}\left(x \mid \mu, \sigma, x_{0}, \alpha, B\right)$

$=\alpha \cdot\left[\frac{1}{x_{0}} \exp \left(\frac{\mu}{x_{0}}+\frac{\sigma^{2}}{2 x_{0}^{2}}-\frac{x}{x_{0}}\right) \Phi\left(\frac{x-\mu}{\sigma}-\frac{\sigma}{x_{0}}\right)\right]+B$,

where $x_{0}$ in the exponential function $e(x)$ is the $e$-folding distance downwind, representing the length scale of the $\mathrm{NO}_{2}$ decay; $\mu$ is the location of the apparent source relative to the city center; $\sigma$ is the standard deviation of the Gaussian function $G(x)$, representing the Gaussian smoothing length scale; $\Phi$ is the cumulative distribution function; $B$ is the offset factor representing the background $\mathrm{NO}_{2} ; f(x)$ is the convolution of $e(x)$ and $G(x)$; and $\alpha$ is the scale factor of $f(x)$. Since the integration of $f(x)$ equals one, the parameter $\alpha$ physically means the total number of $\mathrm{NO}_{2}$ molecules observed near the hotspot, excluding the effect of background $\mathrm{NO}_{2}$. $\alpha$ can be converted to mass units, representing the observed $\mathrm{OMI} \mathrm{NO}_{2}$ burden over the urban areas. Using the mean zonal wind speed $w$ of the $\mathrm{NO}_{2}$ line density domain, the mean effective $\mathrm{NO}_{2}$ lifetime $\tau_{\text {effective }}$ and the mean $\mathrm{NO}_{x}$ emissions $E$ can be calculated from the fitted parameters $x_{0}$ and $\alpha$ as

$\tau_{\text {effective }}=x_{0} / w$,

$E=1.32 \cdot \alpha / \tau_{\text {effective }}=1.32 \cdot \alpha \cdot w / x_{0}$,

where the factor of 1.32 is the mean $\mathrm{NO}_{x} / \mathrm{NO}_{2}$ ratio suggested by Beirle et al. (2011).

We made additional treatments to the $\mathrm{OMI} \mathrm{NO} \mathrm{N}_{2}$ data when using the EMG method. For urban areas surrounded by significant $\mathrm{NO}_{x}$ emission sources, we discarded the OMI data with certain wind directions in the plume rotation process to limit the influence of surrounding sources on the windaligned $\mathrm{OMI} \mathrm{NO}_{2}$ line densities. For example, Washington, DC, is located $\sim 150 \mathrm{~km}$ southwest of Philadelphia. On the one hand, the $\mathrm{NO}_{2}$ of Philadelphia can be transported to Washington, DC, through northeasterly winds and affect the upwind pattern of the OMI line densities of Washington, DC. On the other hand, southwesterly winds can bring the $\mathrm{NO}_{2}$ plume of Washington, $\mathrm{DC}$, to Philadelphia and affect the downwind pattern of the line densities. In this case, daily OMI $\mathrm{NO}_{2}$ maps with azimuths of $15-105^{\circ}$ (i.e., northeasterlies) and $195-285^{\circ}$ (i.e., southwesterlies) were excluded in the map rotation process. As discussed in detail in Sects. 3.1 and 3.2, the EMG method provides more accurate estimates of $\mathrm{NO}_{x}$ emissions for $\mathrm{OMI} \mathrm{NO}_{2}$ line densities obtained at stronger-wind-speed conditions (de Foy et al., 2014; Valin et al., 2013; Ialongo et al., 2014), while $\mathrm{OMI} \mathrm{NO}_{2}$ burdens under weak-wind conditions correlate better with $\mathrm{NO}_{x}$ emissions. We therefore divided the OMI observations into highand low-wind-speed groups (e.g., Fig. 2a and b) and applied the EMG method to both groups. For the high-wind-speeds group, the OMI-derived $\mathrm{NO}_{x}$ emissions $(E)$ and effective $\mathrm{NO}_{2}$ lifetimes ( $\left.\tau_{\text {effective }}\right)$ were estimated and the wind speeds were set to be above thresholds of $3-5 \mathrm{~m} \mathrm{~s}^{-1}$ depending on 

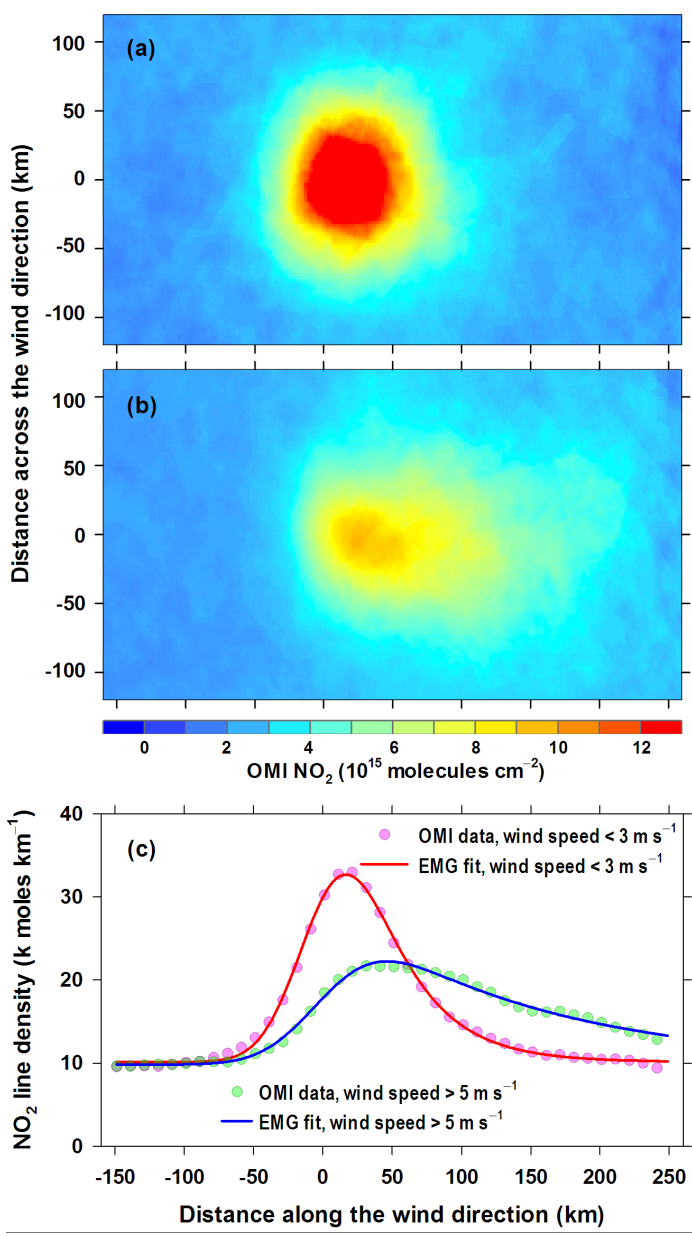

Figure 2. Wind-aligned $\mathrm{OMI} \mathrm{NO}_{2}$ TVCD maps at wind speeds (a) $<3 \mathrm{~m} \mathrm{~s}^{-1}$ and (b) $>5 \mathrm{~m} \mathrm{~s}^{-1}$ for Chicago in summer months (i.e., April-September) during 2005-2007. (c) $\mathrm{OMI} \mathrm{NO}_{2}$ line densities of (a) and (b) and the corresponding EMG fits. Line densities are from the integration of the $\mathrm{NO}_{2}$ data in the across-wind direction.

the wind fields of each urban area. For the low-wind-speeds group, the criterion was set to be below $3 \mathrm{~m} \mathrm{~s}^{-1}$ for all investigated urban areas, and the $\mathrm{OMI} \mathrm{NO}_{2}$ burdens $(\alpha)$ under the slow wind condition were determined. To get reliable estimates through the EMG fit, we further combined all the valid data in 3 consecutive years in the analysis. Therefore, most results shown in this work are 3-year averages or 3-year moving trends. For simplicity, we add an asterisk to the middle year to represent the period of 3 years (e.g., 2006* denotes 2005-2007). Through the abovementioned treatments, there are at least 30 (up to $\sim 250$ ) valid OMI observations covering the line density domain of each urban area for both the highand low-wind-speed cases in any 3 consecutive years during 2005-2014.

We follow the same method used by Beirle et al. (2011) to characterize the uncertainties of the estimates. Unless specified otherwise, the term "uncertainty" in this article refers to 1 standard deviation $( \pm 1 \mathrm{SD})$ or the coefficient of variation
(CV, SD divided by the mean) expressed as a percentage. Total uncertainties of estimated $\mathrm{NO}_{x}$ emissions are the quadrature sum of the uncertainties in the $\mathrm{NO}_{x} / \mathrm{NO}_{2}$ ratio $(10 \%)$, DOMINO v2.0 TVCDs ( $25 \%)$, EMG fitted results, the selected across-wind integration intervals for the line densities $(10 \%)$, and the wind fields (30\%; Beirle et al., 2011; Boersma et al., 2011). The latter four terms are taken into account for estimated $\mathrm{NO}_{2}$ burdens, and the latter three are used in calculating the uncertainties of the effective $\mathrm{NO}_{2}$ lifetimes.

\subsection{Bottom-up $\mathrm{NO}_{x}$ emissions and ground-based $\mathrm{NO}_{2}$ measurements}

The OMI-derived $\mathrm{NO}_{x}$ emissions, $\mathrm{NO}_{2}$ burdens, and their trends for the major US urban areas are compared with both bottom-up $\mathrm{NO}_{x}$ emissions and ground-based $\mathrm{NO}_{2}$ measurements. The bottom-up $\mathrm{NO}_{x}$ emissions are based on the US EPA's National Emission Inventory (NEI; http://www.epa. gov/ttn/chief/eiinformation.html). For each urban area, we grouped the counties covering the major urban extent and the major $\mathrm{OMI} \mathrm{NO}_{2}$ plume and treated the sum of NEI emissions of these counties as the bottom-up $\mathrm{NO}_{x}$ emissions of this urban area. The counties grouped for each urban area are listed in detail in Table $\mathrm{S} 1$ of the Supplement. $\mathrm{NO}_{x}$ emissions at the county level for years 2005, 2008, and 2011 were taken from the NEI directly, and emissions in other years were scaled on the basis of the NEI annual emission trends (http://www.epa.gov/ttn/chief/trends/index.html). We did not take into account $\mathrm{NO}_{x}$ emissions of natural sources such as open biomass burning, soil, and lightning, because they are negligible compared to anthropogenic emissions over urban areas in summer.

The ground-based $\mathrm{NO}_{2}$ measurements are from the US EPA's Air Quality System (AQS) database (Demerjian, 2000) acquired from the EPA's AirData website (http://www.epa. gov/airdata/ad_data.html). We only chose monitoring sites spatially located in the $\mathrm{NO}_{2}$ hotspots of the urban areas and temporally having continuous records in April-September from 2005 to 2014. A total of 110 qualified sites in 35 urban areas were selected and the detailed information is provided in Table S2. Since the OMI daily overpass time is at $\sim$ 13:45 LT, for consistent comparison with the OMI-derived results, we only use hourly $\mathrm{NO}_{2}$ measurements at 13:00 and 14:00 LT in the analysis. The 3-year average $\mathrm{NO}_{2}$ concentration of an urban area is then determined from hourly measurements of all included sites.

\section{Results and discussion}

\subsection{OMI $\mathrm{NO}_{2}$ TVCDs over the continental US and the wind effects}

Figure 1a shows the spatial distribution of average summer OMI NO 2 TVCDs over the US during 2005-2014 with 
all valid OMI pixel data passing the criteria described in Sect. 2.1. The average TVCDs for the periods of 20052007 (i.e., 2006*) and 2012-2014 (i.e., 2013*) are shown in Fig. 3a and b, respectively. Obviously, the $\mathrm{NO}_{2}$ signals of all selected urban areas are identifiable in these maps because the short lifetime of $\mathrm{NO}_{x}$ in the lower atmosphere makes the $\mathrm{NO}_{2}$ TVCDs correlate closely with the surface $\mathrm{NO}_{x}$ emissions (e.g., Kim et al., 2006; Martin et al., 2003; Richter et al., 2005). In terms of the OMI-observed $\mathrm{NO}_{2}$ trend during 2005-2014, a significant reduction in TVCDs of up to $50 \%$ is observed in visible hotspots and an increase of up to $\sim 0.3 \times 10^{15}$ molecules $\mathrm{cm}^{-2}$ is observed in rural areas, particularly in the central Us (Fig. 3c). The hotspot reductions are caused by the technology improvement in the vehicle fleet for the urban areas (Dallmann and Harley, 2010; McDonald et al., 2012) and the mandatory implementation of emission control devices for power plants (Duncan et al., 2013; Kim et al., 2006). The rural increases are believed to be associated with the variations of soil $\mathrm{NO}_{x}$ emissions in recent years (Hudman et al., 2010; Russell et al., 2012). The above $\mathrm{NO}_{2}$ trends over the US have been more or less reported in a number of previous studies (e.g., Kim et al., 2009; Russell et al., 2012; Tong et al., 2015), although we extended our analysis to the most recent year (i.e., 2014). It should be noted that these previous studies were all based on the satellite maps under all-wind conditions, while we will mainly discuss how the winds affect the satellite-observed $\mathrm{NO}_{2}$ signals and trends over the urban areas in the following paragraphs.

The effect of different wind speeds on the patterns of the OMI-observed $\mathrm{NO}_{2}$ columns was first shown by Valin et al. (2013) for Riyadh, Saudi Arabia. Here, we take Chicago as an example to demonstrate this effect. Figures $2 \mathrm{a}$ and $\mathrm{b}$ display the wind-aligned $\mathrm{OMI} \mathrm{NO}_{2}$ TVCD maps of Chicago when wind speeds are slow $\left(<3 \mathrm{~m} \mathrm{~s}^{-1}\right)$ and fast $\left(>5 \mathrm{~m} \mathrm{~s}^{-1}\right)$, respectively. The corresponding $\mathrm{NO}_{2}$ line densities are shown in Fig. 2c. At low wind speeds, $\mathrm{NO}_{x}$ emissions accumulate and stagnate near the urban center, making the peak $\mathrm{NO}_{2}$ columns about twice those observed at high wind speeds, once the background $\mathrm{NO}_{2}$ is removed. In contrast, $\mathrm{NO}_{2}$ plumes can be transported further in high-wind-speed conditions, increasing the downwind $\mathrm{NO}_{2}$ columns at $250 \mathrm{~km}$ from the urban center by $\sim 0.9 \times 10^{15}$ molecules $\mathrm{cm}^{-2}$. These results clearly indicate that the presence of winds, especially high-speed winds, affects the satellite $\mathrm{NO}_{2}$ observations.

In practice, $\mathrm{OMI} \mathrm{NO}_{2}$ TVCD maps are averaged from valid pixel data with winds at different speeds from different directions (e.g., Figs. 1a; 3a, b); and, consequently, $\mathrm{NO}_{2}$ signals near the $\mathrm{NO}_{x}$ emitting sources are smeared spatially. Figure $1 \mathrm{~b}$ shows the summer mean $\mathrm{NO}_{2}$ TVCDs over the US during 2005-2014 at wind speeds $<3 \mathrm{~m} \mathrm{~s}^{-1}$, and the maps for 2005-2007 and 2012-2014 are shown in Fig. 3d and e, respectively. Compared to $\mathrm{NO}_{2}$ maps under the allwind condition, $\mathrm{NO}_{2}$ signals at low wind speeds are obviously higher over the urban areas (as well as in the big iso- lated power plant areas) and lower in surrounding rural areas (Figs. 1c; $3 \mathrm{~g}, \mathrm{~h}$ ) and, consequently, more $\mathrm{NO}_{2}$ hotspots are visible. In summary, satellite $\mathrm{NO}_{2}$ maps for low-wind-speed conditions highlight the $\mathrm{NO}_{x}$ emission sources. This was also demonstrated in a recent study by Ialongo et al. (2014), who used the OMI pixels with wind speeds $<5 \mathrm{~m} \mathrm{~s}^{-1}$ to highlight the $\mathrm{NO}_{x}$ signals of three cities in the Baltic Sea region.

The effect of winds on satellite-observed $\mathrm{NO}_{2}$ columns is not uniform but depends on the characteristics of the wind fields at each urban location. Figure 4 compares the OMI $\mathrm{NO}_{2}$ TVCD maps for Chicago and Los Angeles under the allwind and the weak-wind conditions. Compared to the significant differences in $\mathrm{NO}_{2}$ columns over Chicago, the discrepancies between the weak-wind and the all-wind conditions over Los Angeles are nearly negligible. This is because the wind fields in these two cities are quite different. According to the ERA-interim reanalysis, the average wind speed of Los Angeles in summer during 2005-2014 was $2.4 \mathrm{~m} \mathrm{~s}^{-1}$ and $\sim 80 \%$ of the total valid OMI data were measured under wind speeds of $<3 \mathrm{~m} \mathrm{~s}^{-1}$. However, the average wind speed was $4.8 \mathrm{~m} \mathrm{~s}^{-1}$ for Chicago and the fraction of valid pixel data with wind speeds $<3 \mathrm{~m} \mathrm{~s}^{-1}$ was only $\sim 25 \%$. Figure 4 also shows that the $\mathrm{OMI} \mathrm{NO}_{2}$ signals observed at low wind speeds are better correlated with the $\mathrm{NO}_{x}$ emissions. Comparing OMI maps under the all-wind condition (Fig. 4a vs. 4d), Chicago seems to have significantly lower $\mathrm{NO}_{x}$ emissions than Los Angeles. However, on the basis of the NEI, average $\mathrm{NO}_{x}$ emissions from Chicago were about three-quarters of those from Los Angeles during 2005-2014 (Table 1). After removing the pixels with strong winds, the $\mathrm{OMI} \mathrm{NO}$ signals of Chicago and Los Angeles match the amounts of their NEI $\mathrm{NO}_{x}$ emissions much better.

For the reasons discussed above, in contrast to previous studies that use all-wind $\mathrm{NO}_{2}$ maps, we utilize the OMI data under weak-wind conditions to calculate the satelliteobserved $\mathrm{NO}_{2}$ columns, burdens, and trends in the quantities in this work. The threshold of the wind speed was chosen to be $3 \mathrm{~m} \mathrm{~s}^{-1}$ for all the urban areas to ensure enough valid OMI samples (> 30 in 3 consecutive years). However, we do not discard the OMI data under the strong wind conditions, but use them with the EMG method to obtain "top-down" $\mathrm{NO}_{x}$ emissions (see Sect. 2.4 and the following sections). It should be noted that the presence of the strong winds may also change the observed $\mathrm{NO}_{2}$ trends. Figure $3 \mathrm{i}$ shows the differences in OMI $\mathrm{NO}_{2}$ changes over the US between the weak-wind and the all-wind conditions. Greater $\mathrm{NO}_{2}$ reductions from $2005 *$ to $2013 *$ are observed under the weak-wind condition than under the all-wind condition over a number of cities, including Chicago, Minneapolis, New York, Las Vegas, and Cincinnati. This is possibly related to the nonlinearity of the $\mathrm{NO}_{x}$ chemistry. At fast wind speeds, the decreased $\mathrm{NO}_{2}$ level over polluted urban areas may increase the $\mathrm{NO}_{x}$ lifetime so that the same reduction in $\mathrm{NO}_{x}$ emissions would lead to a smaller reduction in observed $\mathrm{NO}_{2}$ columns compared to the slow-wind-speed conditions. For this reason, it 


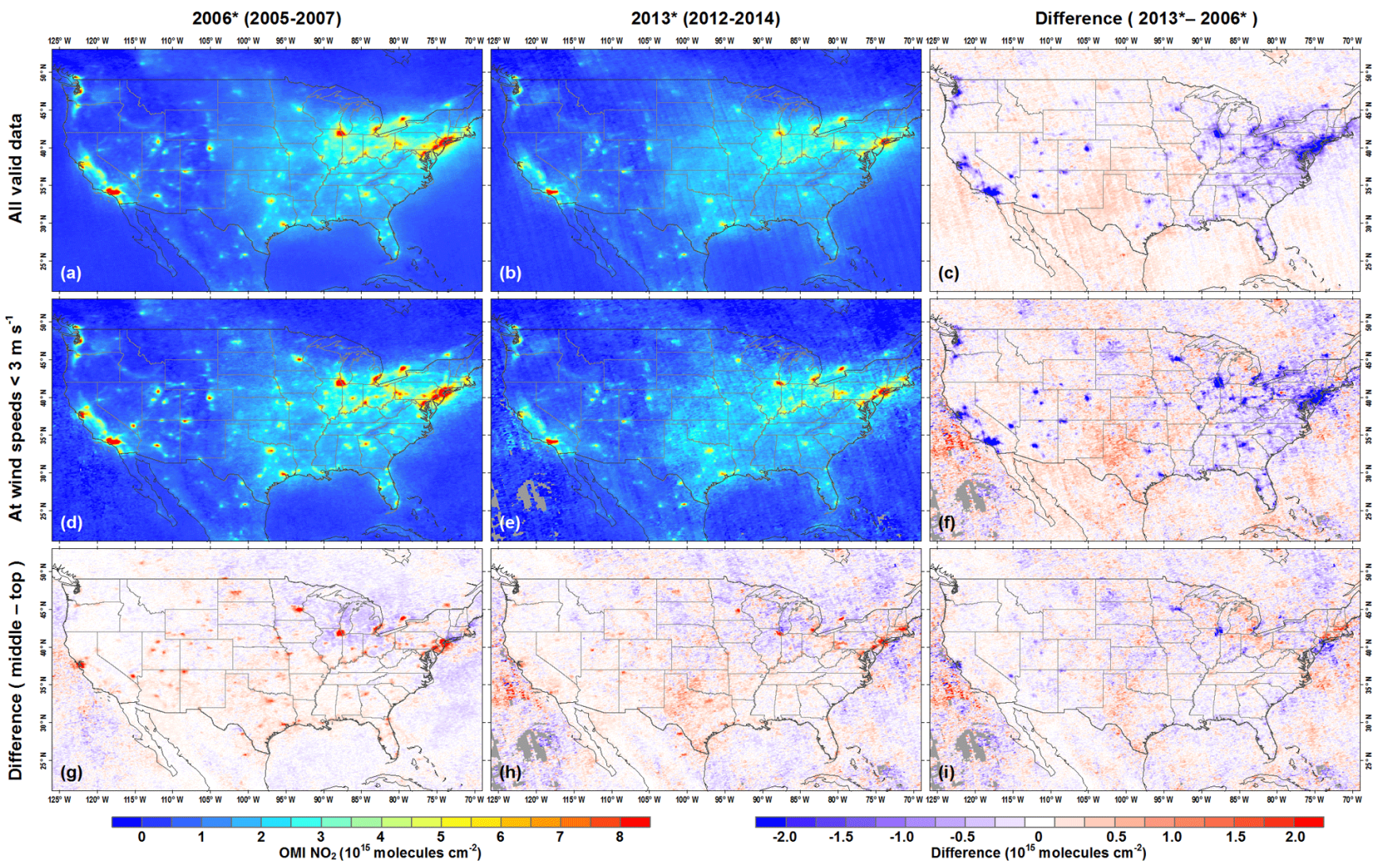

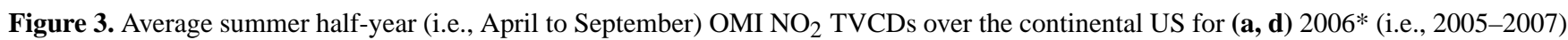
and (b, e) 2013* (i.e., 2012-2014): (a, b) all valid data were used, (d, e) only valid data with wind speeds $<3 \mathrm{~m} \mathrm{~s}^{-1}$ were used. The right column shows the differences in maps between the middle and the left column. The bottom row shows the differences in maps between the middle and the top row.

is expected that we would derive a higher rate of decline in OMI $\mathrm{NO}_{2}$ columns over US urban areas than previous studies that have used all-wind OMI data.

\section{2 $\mathrm{NO}_{x}$ emissions of US urban areas estimated from the $\mathrm{OMI}$ retrievals}

As mentioned in Sect. 2.4, we use the EMG method to estimate $\mathrm{NO}_{x}$ emissions from US urban areas. In the original EMG method presented by Beirle et al. (2011), an average wind speed of at least $2 \mathrm{~m} \mathrm{~s}^{-1}$ was required for a target area to guarantee clear downwind outflow $\mathrm{NO}_{2}$ patterns. However, Valin et al. (2013) pointed out that the variations of wind speed impact the nonlinear $\mathrm{NO}_{x}$ chemistry, and the $\mathrm{NO}_{2}$ lifetime (and $\mathrm{NO}_{x}$ emissions) inferred from the average spatial pattern of the $\mathrm{NO}_{2}$ plume is not necessarily equal to the average lifetime (and emissions). They restricted their analysis to OMI measurements made when winds were fast (i.e., $>6.4 \mathrm{~m} \mathrm{~s}^{-1}$ ) because under this condition the downwind decay of $\mathrm{NO}_{2}$ is dominated by chemical removal, not variability of the winds. In fact, instead of using $6.4 \mathrm{~m} \mathrm{~s}^{-1}$, the same emission estimates would be obtained if they had used the OMI measurements with wind speed $>5 \mathrm{~m} \mathrm{~s}^{-1}$ (see Fig. 4 of Valin et al., 2013). Recently, de Foy et al. (2014) evaluated the EMG method using simulated column densities over an ideal point source with different chemical lifetimes and wind speeds. They found that the EMG method provided fairly robust and accurate emission estimates when wind speeds were $>3 \mathrm{~m} \mathrm{~s}^{-1}$. Furthermore, the EMG-obtained emissions seemed to be more accurate when wind speeds were higher, especially for case of the chemical lifetime $<12 \mathrm{~h}$ (see Table 2 of de Foy et al., 2014). In this work, we therefore apply the EMG method to the OMI line densities under strongwind-speed conditions to estimate $\mathrm{NO}_{x}$ emissions. The criterion for the wind speed was set to be $>5 \mathrm{~m} \mathrm{~s}^{-1}$ and, if necessary, relaxed to 4 or $3 \mathrm{~m} \mathrm{~s}^{-1}$ to ensure at least 30 valid OMI samples in 3 consecutive years.

Again, we use the example of Chicago to demonstrate our analytical procedure. Figure $2 \mathrm{~b}$ shows the wind-aligned OMI $\mathrm{NO}_{2}$ TVCDs at wind speeds $>5 \mathrm{~m} \mathrm{~s}^{-1}$ for Chicago during 2005-2007 (i.e., the year 2006*). The $\mathrm{NO}_{2}$ line densities and the corresponding EMG fit are shown in Fig. 2c. Clearly, the EMG fit reproduces the $\mathrm{NO}_{2}$ pattern along the wind direction very well. The fitted $e$-folding distance $x_{0}$, background 


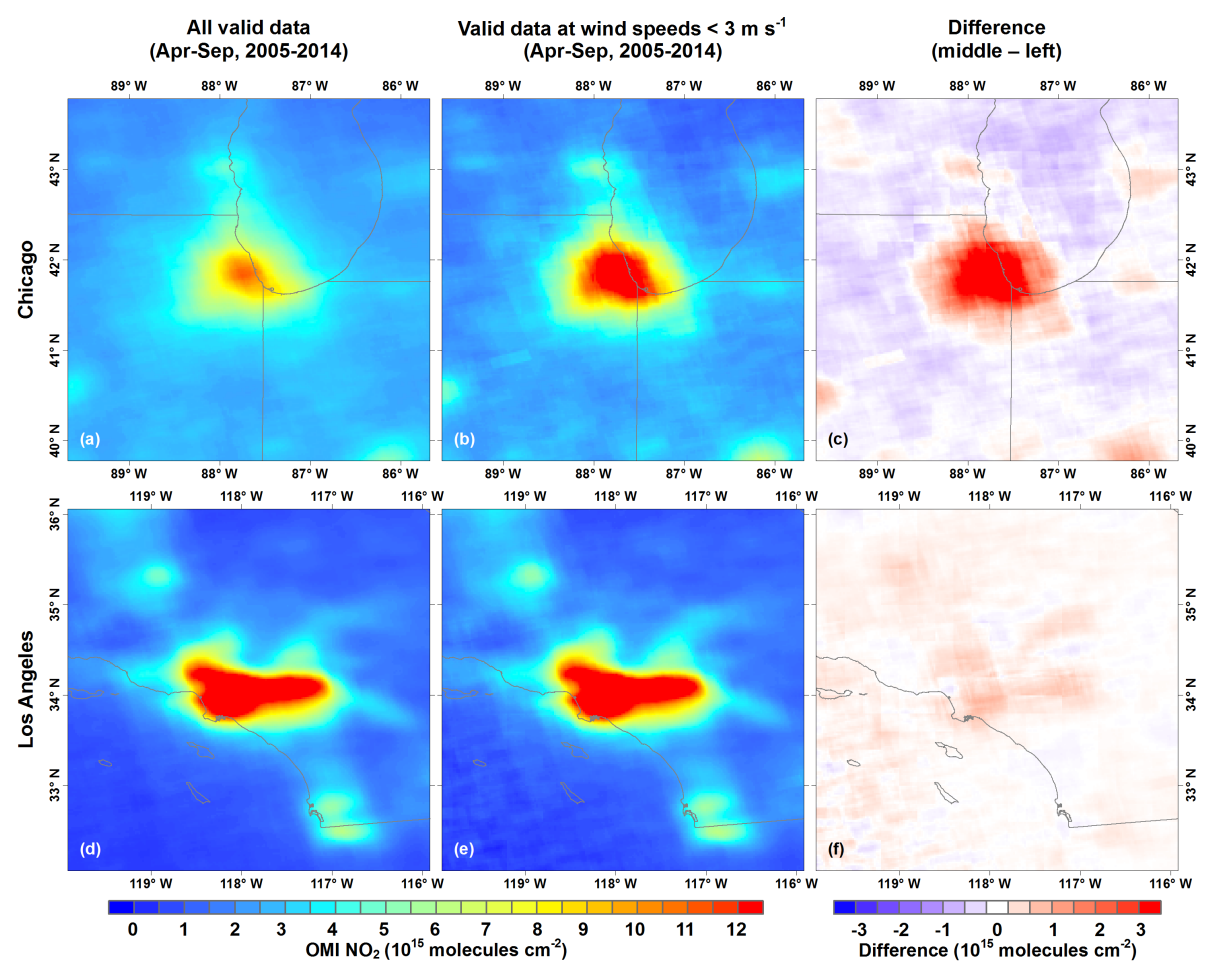

Figure 4. Average summer half-year (i.e., April-September) $\mathrm{OMI} \mathrm{NO} 2 \mathrm{TVCD}$ over (a, b) Chicago and (d, e) Los Angeles during 20052014: (a, d) all valid data were used, $(\mathbf{b}, \mathbf{e})$ only valid data with wind speeds $<3 \mathrm{~m} \mathrm{~s}^{-1}$ were used, and (c, f) the difference between the middle and the left column.

$B$, and the burden $\alpha$ are $144 \mathrm{~km}, 9.83 \times 10^{3} \mathrm{~mol} \mathrm{~km}^{-1}$, and $2.74 \times 10^{6} \mathrm{~mol}$, respectively. The average wind speed $w$ of valid OMI pixels over the studied domain is $7.3 \mathrm{~m} \mathrm{~s}^{-1}$, so that the effective $\mathrm{NO}_{2}$ lifetime $\tau_{\text {effective }}$ and the $\mathrm{NO}_{x}$ emissions $E$ are determined to be $5.5 \mathrm{~h}$ and $30 \mathrm{Mg} \mathrm{h}^{-1}$ through Eqs. (5) and (6), respectively. We also use the EMG method to fit the $\mathrm{NO}_{2}$ line densities at wind speeds $<3 \mathrm{~m} \mathrm{~s}^{-1}$ (see Fig. 2 and Sect. 3.1), and the $\mathrm{OMI} \mathrm{NO}_{2}$ burden under the weak-wind condition is estimated to be $98 \mathrm{Mg}$. The same analysis is conducted for all the 3 consecutive years during 2005-2014 and the 3-year moving $\mathrm{NO}_{2}$ and $\mathrm{NO}_{x}$ trends are summarized in Fig. 5. Results show that the four $\mathrm{NO}_{x}$-related trends in Chicago correlate with each other very well from 2006* to $2013 *(R>0.89)$. The linear annual average decreasing rates (AADRs) of the OMI-derived $\mathrm{NO}_{x}$ emissions, the OMIobserved $\mathrm{NO}_{2}$ burdens at slow winds, the NEI $\mathrm{NO}_{x}$ emission estimates, and the ground-based $\mathrm{NO}_{2}$ measurements are $-7.8,-5.7,-6.6$, and $-6.8 \% \mathrm{yr}^{-1}$, respectively. The AADRs of the OMI-observed $\mathrm{NO}_{2}$ burden is greater than previously reported values of -3.9 to $-5.4 \% \mathrm{yr}^{-1}$ that use the all-wind satellite $\mathrm{NO}_{2}$ maps (Lamsal et al., 2015; Hilboll et al., 2013; Schneider et al., 2015; Russell et al., 2012) but close to those of the "top-down" and "bottom-up" emissions as well as surface measurements. This further implies that the presence of strong winds changes the observed $\mathrm{NO}_{2}$ trends, and trends in $\mathrm{NO}_{2}$ columns obtained at slow winds may better reflect the real bottom-up $\mathrm{NO}_{x}$ emission trends.

The above analysis procedure was applied to all 35 selected US urban areas and the average $\mathrm{NO}_{x}$-related quantities and linear trends for the entire period of $2006 *-2013^{*}$ are summarized in Table 1 . We focus on the relationship between $\mathrm{NO}_{x}$ emissions and $\mathrm{NO}_{2}$ burdens in this section and discuss the trends in the next section. Figures $6 \mathrm{a}$ and $\mathrm{b}$ show the scatter plots of both the NEI and the OMI-derived $\mathrm{NO}_{x}$ emissions against the $\mathrm{OMI} \mathrm{NO}_{2}$ burdens under slow-wind conditions. Each point in the scatter plots represents a 3year moving average for an urban area. Clearly, there is good agreement between $\mathrm{NO}_{x}$ emissions and $\mathrm{OMI} \mathrm{NO}_{2}$ burdens $(R>0.95)$, implying a linear response of the OMI observations to the surface emissions under the weak-wind condition. Generally, urban areas with $\mathrm{NO}_{x}$ emission intensities higher than $\sim 2 \mathrm{Mg} \mathrm{h}^{-1}$ produce statistically significant OMI burdens and can be analyzed using the method described in this work.

Figure $6 \mathrm{c}$ shows the comparison between the OMI-derived and the NEI $\mathrm{NO}_{x}$ emissions for all the selected urban areas. Good agreement was also found between the top-down and the bottom-up emission estimates $(R=0.94)$. The slope of the linear fit indicates that the NEI emissions are on average $\sim 6 \%$ higher than the OMI-derived ones. Besides the uncertainties of both estimates, any remaining discrepancies can 
Table 2. Summary of $\mathrm{NO}_{x}$-related trends over all selected US urban areas during $2006 *-2013 * \mathrm{a}$.

\begin{tabular}{lccc}
\hline & $2006^{*}-2013^{*}$ & $2006^{*}-2010^{*}$ & $2010^{*-2013 *}$ \\
\hline Sum of $\mathrm{OMI} \mathrm{NO}_{2}$ columns under winds $<3 \mathrm{~m} \mathrm{~s}^{-1}$ & $-6.9 \% \mathrm{yr}^{-1}$ & $-9.0 \% \mathrm{yr}^{-1}$ & $-3.9 \% \mathrm{yr}^{-1}$ \\
Total NEI $\mathrm{NO}_{x}$ emissions & $-6.2 \% \mathrm{yr}^{-1}$ & $-6.8 \% \mathrm{yr}^{-1}$ & $-4.9 \% \mathrm{yr}^{-1}$ \\
Total OMI-derived $\mathrm{NO}_{x}$ emissions & $-7.4 \% \mathrm{yr}^{-1}$ & $-8.7 \% \mathrm{yr}^{-1}$ & $-3.4 \% \mathrm{yr}^{-1}$ \\
Total $\mathrm{OMI} \mathrm{NO}_{2}$ burdens under winds $<3 \mathrm{~m} \mathrm{~s}^{-1}$ & $-7.3 \% \mathrm{yr}^{-1}$ & $-9.3 \% \mathrm{yr}^{-1}$ & $-4.6 \% \mathrm{yr}^{-1}$ \\
Average $\mathrm{NO}_{2}$ concentrations & $-6.3 \% \mathrm{yr}^{-1}$ & $-7.2 \% \mathrm{yr}^{-1}$ & $-4.6 \% \mathrm{yr}^{-1}$ \\
\hline
\end{tabular}

a 2006*, 2010*, and 2013* denote the 3-year average of 2005-2007, 2009-2011, and 2012-2014, respectively.

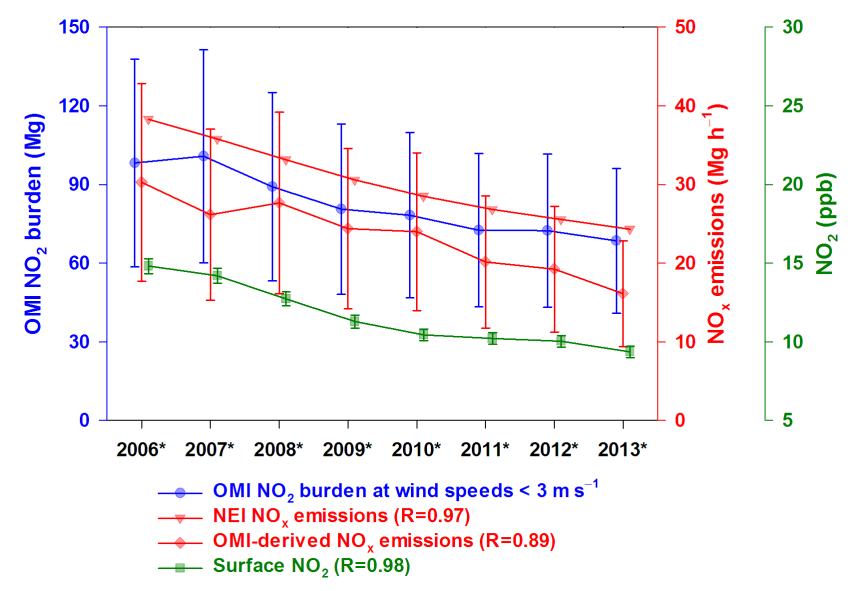

Figure 5. Interannual trends of $\mathrm{NEI} \mathrm{NO}_{x}$ emissions, the OMIderived summertime (April-September) $\mathrm{NO}_{x}$ emissions, the OMIobserved summertime $\mathrm{NO}_{2}$ burdens at low-wind-speed $\left(<3 \mathrm{~m} \mathrm{~s}^{-1}\right)$ conditions, and the average summertime $\mathrm{NO}_{2}$ concentrations at 13:00-14:00 LT in Chicago during 2006*-2013*. Error bars express the $\pm 1 \mathrm{SD}$ of the annually estimated results. $R$ values shown are the correlation coefficients with the OMI-observed $\mathrm{NO}_{2}$ burdens.

probably be attributed to three factors. First, the NEI $\mathrm{NO}_{x}$ emissions of an urban area are based on the sum of all emissions in counties covering the major urban extent and the major $\mathrm{OMI} \mathrm{NO}_{2}$ plume. Since the outer boundary of the urban area is often somewhat larger than its OMI signals, the NEI values may include more emissions. Second, the OMIderived $\mathrm{NO}_{x}$ emissions are for the summer half-year, while we did not take into account the seasonality of the NEI emissions. Generally, $\mathrm{NO}_{x}$ emissions of urban areas are lower in summer than in winter because of the relatively low vehicle emissions on warm days and the higher rates of operation of $\mathrm{NO}_{x}$ control devices in some power plants during the ozone season (e.g., Xing et al., 2013; Duncan et al., 2013). Third, a typical $\mathrm{NO}_{x} / \mathrm{NO}_{2}$ ratio of 1.32 at noon was used in the determination of $\mathrm{NO}_{x}$ emissions, but this scale factor may vary in urban areas depending on the local $\mathrm{NO}_{x}$ chemistry.

In addition to the $\mathrm{NO}_{x}$ emissions, the EMG fits for the OMI line densities at strong winds also yield instantaneous daytime (or, more precisely, 13:00-14:00 LT) lifetimes of
$\mathrm{NO}_{2}$ for selected urban areas. The model evaluation by de Foy et al. (2014) showed that the EMG method provides accurate estimates of the chemical lifetimes $\left(\tau_{\text {chemical }}\right)$ if the plumes are uniformly transported at fast winds (i.e., $5 \mathrm{~m} \mathrm{~s}^{-1}$ ). However, influenced by the inaccurate plume rotation and the use of the satellite data at relatively slow wind speeds, they found the resulting lifetimes were always biased low and could not be treated as the true $\tau_{\text {chemical }}$. Here, we call this term the effective lifetime ( $\left.\tau_{\text {effective }}\right)$, which can be considered as a combination of $\tau_{\text {chemical }}$ and an extra lifetime term of $\tau_{\text {extra }}$ related to the influences of plume meandering, grid resolution, and sampling issues (i.e., lifetimes are combined inversely as shown in Eq. 7; de Foy et al., 2014, 2015). As summarized in Table 1 , the estimated $\tau_{\text {effective values were }}$ in the range of $1.2-6.8 \mathrm{~h}$ with a mean of $\sim 3.5 \pm 1.3 \mathrm{~h}$ for all studied urban areas during 2005-2014. They are biased low in comparison to the expected summertime $\mathrm{NO}_{2} \tau_{\text {chemical }}$ of $\sim 7 \mathrm{~h}$ estimated for a broader region in the eastern United States (Lamsal et al., 2010) confirming the findings by de Foy et al. (2014), but are consistent with previously reported summertime $\mathrm{NO}_{2}$ lifetimes of $1-7 \mathrm{~h}$ examined for plumes over urban areas (Beirle et al., 2011; Dommen et al., 1999; Ialongo et al., 2014; Nunnermacker et al., 1998; Spicer, 1982), power plants (Fioletov et al., 2015; Nunnermacker et al., 2000; Sillman, 2000), and open biomass burning (Alvarado et al., 2010; Mebust et al., 2011).

It should be noted that the slope of the regression lines of $\sim 2.8 \mathrm{~h}$ in Fig. $6 \mathrm{a}$ and $\mathrm{b}$ is also a time term. It can be considered an average timescale of the OMI-observed $\mathrm{NO}_{2}$ residency over the emission sources under the slow-wind condition. We therefore name it the residence lifetime $\tau_{\text {residence }}$ as suggested by de Foy et al. (2014). In addition to $\tau_{\text {effective, }}$, $\tau_{\text {residence }}$ includes the influences of $\mathrm{NO}_{2}$ physical dispersion in the atmosphere and can be calculated approximately as

$\frac{1}{\tau_{\text {residence }}}=\frac{1}{\tau_{\text {dispersion }}}+\frac{1}{\tau_{\text {effective }}}=\frac{1}{\tau_{\text {dispersion }}}+\frac{1}{\tau_{\text {chemical }}}+\frac{1}{\tau_{\text {extra }}}$,

where $\tau_{\text {dispersion }}$ is the physical dispersion timescale. For the slow-wind-speeds condition, the average dimension of the fitting domain downwind from the urban center was $150 \mathrm{~km}$ and the average wind speed was $2 \mathrm{~m} \mathrm{~s}^{-1}$. Hence, $\tau_{\text {dispersion }}$ was about $21 \mathrm{~h}$ and the average $\tau_{\text {residence }}$ for all the urban areas was estimated to be $\sim 3 \mathrm{~h}$ using Eq. (7), assuming that 

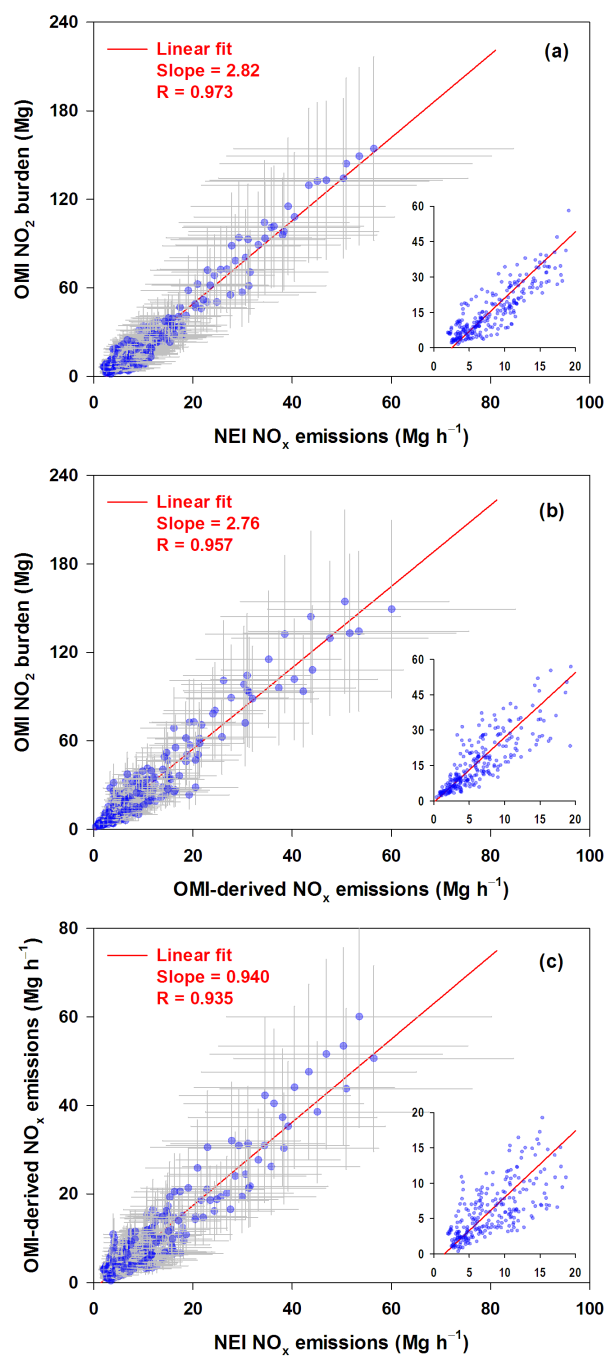

Figure 6. Scatter plots of (a) OMI-observed $\mathrm{NO}_{2}$ burdens at lowwind-speed $\left(<3 \mathrm{~m} \mathrm{~s}^{-1}\right)$ condition against NEI $\mathrm{NO}_{x}$ emissions, (b) OMI-observed $\mathrm{NO}_{2}$ burdens against OMI-derived $\mathrm{NO}_{x}$ emissions, and (c) OMI-derived $\mathrm{NO}_{x}$ emissions against $\mathrm{NEI} \mathrm{NO}_{x}$ emissions for 35 selected US urban areas during 2005-2014. Each point represents a 3-year result for an urban area. Error bars express the \pm 1 SD uncertainties. Uncertainties of NEI emissions are set to be $50 \%$ according to the expert judgment. The inset figures are the enlarged views of points with emissions $<20 \mathrm{Mg} \mathrm{h}^{-1}$.

$\tau_{\text {effective }}$ did not change significantly with wind speed. This $\tau_{\text {residence }}$ estimation is close to the ones derived directly from Fig. $6 \mathrm{a}$ and $\mathrm{b}$ (i.e., $2.8 \mathrm{~h}$ ).

\section{3 $\mathrm{NO}_{2}$ and $\mathrm{NO}_{x}$ trends of US urban areas during 2005-2014}

The linear trends of the NEI $\mathrm{NO}_{x}$ emissions, OMI-derived $\mathrm{NO}_{x}$ emissions, OMI burdens under the weak-wind condition, and the AQS $\mathrm{NO}_{2}$ measurements for all 35 selected urban areas from 2006* to 2013* are summarized in Table 1.

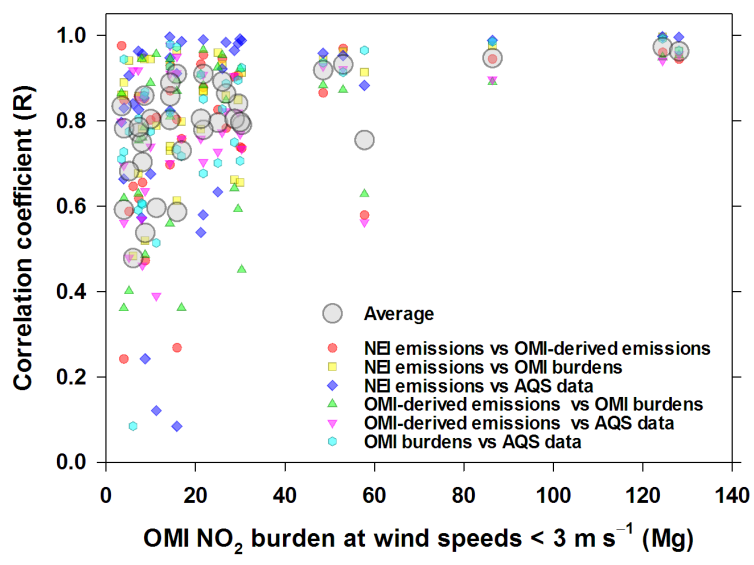

Figure 7. Correlation coefficients of pair-wise trends among the $\mathrm{NEI} \mathrm{NO}_{x}$ emissions, the OMI-derived $\mathrm{NO}_{x}$ emissions, the $\mathrm{OMI}$ $\mathrm{NO}_{2}$ burdens at wind speeds $<3 \mathrm{~ms}^{-1}$, and the AQS $\mathrm{NO}_{2}$ measurements against the mean $\mathrm{OMI} \mathrm{NO}_{2}$ burdens under the weakwind-speed condition $\left(<3 \mathrm{~m} \mathrm{~s}^{-1}\right)$ for all selected urban areas during $2006^{*}-2013^{*}$. Each large gray circle represents the average of the six correlation coefficients for an urban area.

We have calculated the correlation coefficients of pair-wise trends among these four $\mathrm{NO}_{x}$-related quantities for each area (see Table 1) and plotted them against the average OMIobserved $\mathrm{NO}_{2}$ burdens in Fig. 7. Significant reductions in $\mathrm{NO}_{2}$ and $\mathrm{NO}_{x}$ have occurred in US urban areas. The average percentage reductions among all the studied urban areas from $2006 *$ to $2013 *$ were $-34 \pm 12,-46 \pm 13,-45 \pm 15$, and $-37 \pm 12 \%$ for the NEI $\mathrm{NO}_{x}$ emissions, OMI-derived $\mathrm{NO}_{x}$ emissions, OMI-observed $\mathrm{NO}_{2}$ burdens, and surface $\mathrm{NO}_{2}$ measurements, respectively. In general, the time series of the four $\mathrm{NO}_{x}$-related quantities correlate with each other very well in most of the areas. As shown in Fig. 7 and the last column of Table 1, 20 out of the 35 urban areas have an average correlation coefficient $>0.8$, and only 6 areas have an average correlation coefficient $<0.7$. The $\mathrm{NO}_{x}$-related trends are in better agreement with each other for the larger OMI $\mathrm{NO}_{2}$ hotspots such as New York, Los Angeles, Chicago, Philadelphia, and Washington, DC (mean $R>0.92$ ). The poorest correlation among the four $\mathrm{NO}_{x}$-related series is observed in New Orleans (mean $R=0.48$ ), where $\mathrm{NO}_{x}$ emissions are close to the lowest detection limit of the EMG method we suggested in Sect. $3.2\left(\sim 2 \mathrm{Mg} \mathrm{h}^{-1}\right)$.

The differences in trends of the four $\mathrm{NO}_{x}$-related quantities in individual urban areas can be attributed to the following reasons. For the OMI-derived $\mathrm{NO}_{2}$ and $\mathrm{NO}_{x}$ emissions, we have discussed previously that the selection of the wind-speed group and inaccuracy in the wind rotation affects the observed $\mathrm{NO}_{2}$ trends and the EMG fitted results. Moreover, the EMG method is best suited to point sources; however, urban $\mathrm{NO}_{x}$ emissions are area sources, and the size and shape of the urban area may introduce additional uncertainty to the EMG results. For the NEI emissions, although 
$\mathrm{NO}_{x}$ emissions from power plants are measured directly using the continuous emissions monitoring system (CEMS), emissions from other sources (e.g., mobile emissions) are still estimated using bottom-up approaches, which have significant uncertainties inherent in the emission factors and the emissions models that are used (US EPA, 1996). For the AQS data, $\mathrm{NO}_{2}$ measurements at a limited number of monitoring sites can be readily influenced by nearby emission sources and thus may sometimes reflect localized trends rather than urban-scale trends (e.g., Lamsal et al., 2015). Last but not least, there are spatial and temporal mismatches among emissions, OMI observations, and AQS data (e.g., Tong et al., 2015; Bechle et al., 2013). Spatially, OMI provides measurements of tropospheric $\mathrm{NO}_{2}$ column densities, $\mathrm{AQS}$ data are so-called "nose-level" $\mathrm{NO}_{2}$ concentrations, while emissions are $\mathrm{NO}_{x}$ masses directly discharged into the atmosphere at a variety of heights above the surface. Temporally, the NEI emissions are annual estimates, the OMI data were restricted to the summer half-year and have gone through a series of filtering processes to remove unreliable pixels, and although we restricted our analysis to the hourly $\mathrm{NO}_{2}$ measurements close to the OMI overpass time, all AQS measurements at the chosen sites in April-September were used for the trend comparison.

Despite the trend discrepancies caused by these various factors in individual urban areas, we expect the trends of the total (or averaged) $\mathrm{NO}_{x}$ emissions, columns, burdens, and concentrations across all areas to be robust and to reflect the urban $\mathrm{NO}_{x}$ situation at the national level. Figure 8 shows the sum of 3-year averaged OMI $\mathrm{NO}_{2}$ columns under the weakwind-speed condition for all urban areas as a function of the distance from the urban centers. Clearly, the sum of OMI signals over the hotspot centers was continuously decreasing during 2006*-2013*. Based on the 2013*/2006* ratio, OMI $\mathrm{NO}_{2}$ columns over US urban areas decreased by $40 \%$ with an AADR of $-6.9 \% \mathrm{yr}^{-1}$. The 3-year moving trends of the total NEI $\mathrm{NO}_{x}$ emissions, OMI-derived $\mathrm{NO}_{x}$ emissions, OMI-observed $\mathrm{NO}_{2}$ burdens under slow-wind-speed conditions, and the area-weighted average $\mathrm{NO}_{2}$ concentrations for all areas are shown in Fig. 9. The four $\mathrm{NO}_{x}$ or $\mathrm{NO}_{2}$ trends are in excellent agreement with each other $(R>0.99)$. From 2006* to $2013 *$, total NEI $\mathrm{NO}_{x}$ emissions, OMI-derived $\mathrm{NO}_{x}$ emissions, OMI-observed $\mathrm{NO}_{2}$ burdens, and the average $\mathrm{NO}_{2}$ concentrations decreased by $36,42,41$, and $37 \%$ with AADRs of $-6.2,-7.4,-7.3$, and $-6.3 \% \mathrm{yr}^{-1}$, respectively (Table 2). The satellite-observed $\mathrm{NO}_{2}$ rates of decrease obtained in this work are greater than previously reported values. For example, using the OMI BEHR (Berkeley HighResolution) retrievals, Russell et al. (2012) detected consistent decreases in $\mathrm{NO}_{2}$ columns (AADR of $-6.2 \% \mathrm{yr}^{-1}$ ) over 47 US cities during 2005-2011; Tong et al. (2015) examined the OMI $\mathrm{NO}_{2}$ columns over eight large US cities and found an average AADR of $-6.0 \% \mathrm{yr}^{-1}$ for 20052012; with the newly developed NASA OMI product (version 2.2), Lamsal et al. (2015) quantified the average de-

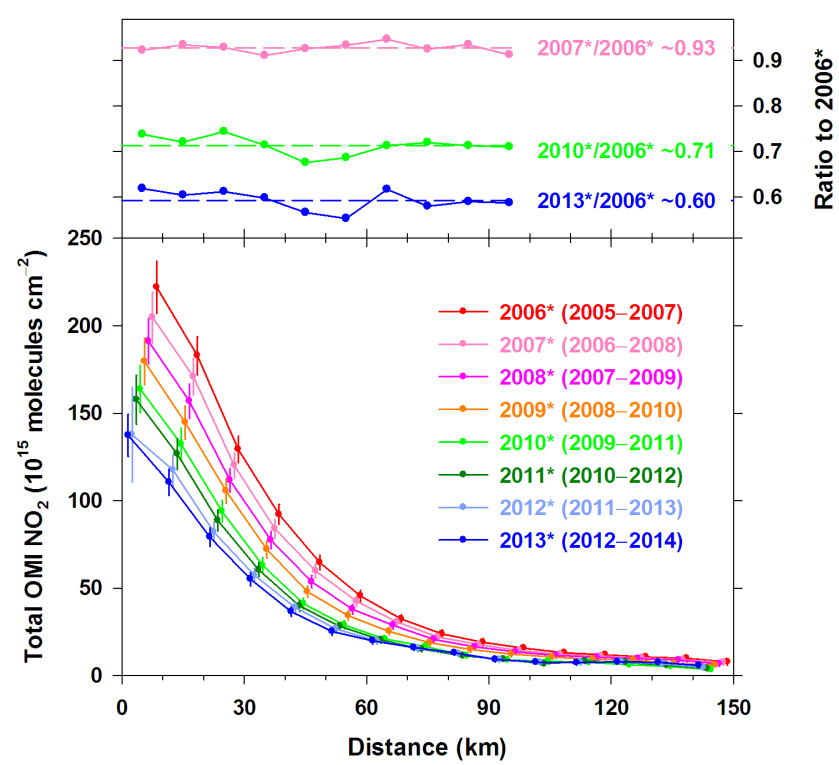

Figure 8. The sum of 3-year averaged OMI $\mathrm{NO}_{2}$ TVCDs under the weak-wind-speed condition for 35 selected US urban areas as a function of the distance from the urban centers during 2006*2013*. The background $\mathrm{NO}_{2}$ of urban areas was removed. Error bars express the $95 \%$ confidence intervals of the mean. The $2007 * / 2006^{*}, 2010 * / 2006^{*}$, and $2013 * / 2006^{*}$ ratios are shown at the top.

creasing rate of $\mathrm{NO}_{2}$ columns in 20 major US cities from 2005 to 2013 to be $-5.8 \% \mathrm{yr}^{-1}$; and Schneider et al. (2015) used the data from the SCIAMACHY (Scanning Imaging Absorption Spectrometer for Atmospheric Chartography) instrument onboard the Envisat platform and observed decreasing tropospheric $\mathrm{NO}_{2}$ columns on the order of $-5.8 \% \mathrm{yr}^{-1}$ over nine large urban agglomerations in the US for the period of 2002-2012. Although these previous studies differ in a number of aspects such as satellite data used (i.e., instruments/retrievals/products), time period studied (i.e., summer months or all months), urban areas selected, domain size chosen for each area, trend calculation method used, etc., they derived similar average $\mathrm{NO}_{2}$ column decrease rates of -5.8 to $-6.2 \% \mathrm{yr}^{-1}$ for US cities since $\sim 2005$. This implies that the differences mentioned above may have minor influence on the overall trend analysis results at the country or regional level. However, we obtain a significantly greater column decrease rate of $-7.3 \% \mathrm{yr}^{-1}$ in this work. As discussed in Sect. 3.1, the fact that all these previous studies used all-wind satellite $\mathrm{NO}_{2}$ maps while we used weak-wind OMI data is the major reason for such discrepancy.

In previous studies such as Russell et al. (2012), Tong et al. (2015), and Lamsal et al. (2015), OMI $\mathrm{NO}_{2}$ reduction rates were observed to be moderate $\left(\sim-7 \% \mathrm{yr}^{-1}\right)$, larger $\left(\sim-9 \% \mathrm{yr}^{-1}\right)$, and smaller $\left(\sim-3 \% \mathrm{yr}^{-1}\right)$ during the periods of 2005-2007, 2008-2009, and after 2010, respectively, over the US urban areas. The reason for these changes of 
pace of the reduction was attributed in these previous studies to the combined effects of the gradually installed $\mathrm{NO}_{x}$ control devices in power plants, transformation to a lesspolluting vehicle fleet, the economic recession that happened in 2008, and the slow recovery of the US economy after 2008. In this work, we found similar trends. As shown in Figs. 8 and 9, the sum of OMI columns, the total NEI NO emissions, OMI-derived $\mathrm{NO}_{x}$ emissions, $\mathrm{OMI} \mathrm{NO}_{2}$ burdens, and the average $\mathrm{NO}_{2}$ concentrations over selected urban areas decreased at rates of -6.8 to $-9.3 \% \mathrm{yr}^{-1}$ during $2006^{*}$ $2010 *$, and -3.4 to $-4.6 \% \mathrm{yr}^{-1}$ during $2010^{*}-2013^{*}$ (Table 2). We did not observe a greater decreasing rate during the economic recession period, probably because we used 3year moving trends which smooth the short-term changes. Extrapolating the trends to the years of 2005 and 2014 with AADRs of earlier and later periods, respectively, we estimate that the above five $\mathrm{NO}_{x}$-related quantities decreased by approximately $47,43,49,49$, and $44 \%$, respectively, during the whole period of 2005-2014.

Although satellite $\mathrm{NO}_{2}$ column changes cannot be translated to $\mathrm{NO}_{x}$ emission changes directly, due to the nonlinear feedback of $\mathrm{NO}_{x}$ emissions on $\mathrm{NO}_{x}$ chemistry (Lamsal et al., 2011; Lu and Streets, 2012), we indeed obtained similar reductions in total $\mathrm{NO}_{x}$ emissions and total OMI $\mathrm{NO}_{2}$ observations over all the selected urban areas in the US. Lamsal et al. (2011) used a dimensionless factor of $\beta$ to express the relationship between changes in $\mathrm{NO}_{x}$ emissions and changes in $\mathrm{NO}_{2}$ TVCDs:

$\beta=\frac{\Delta E / E}{\Delta \mathrm{TVCD} / \mathrm{TVCD}}$

Generally, $\beta$ is greater than one in clean regions, because increased $\mathrm{NO}_{x}$ emissions under the low $\mathrm{NO}_{2}$ condition promotes the generation of $\mathrm{OH}$ radicals and thus decreases the $\mathrm{NO}_{x}$ lifetime, while $\beta$ is less than one in polluted regions since an increase in $\mathrm{NO}_{x}$ emissions consumes $\mathrm{OH}$ radicals and increases the $\mathrm{NO}_{x}$ lifetime. On the basis of the monthly global gridded $\beta$ calculated by Lamsal et al. (2011), the average $\beta$ over the 35 selected urban areas during AprilSeptember was $1.03 \pm 0.21$ (bounding values $0.74-1.52$ ). This result partially explains why we observed similar trends in total $\mathrm{NO}_{x}$ emissions and total $\mathrm{OMI} \mathrm{NO}_{2}$ columns in this work. It should be noted that we only discuss the overall atmospheric characteristics over all urban areas here. Individual areas may have $\beta$ values significantly greater or smaller than one, reflecting the local sensitivity of changes in OMI $\mathrm{NO}_{2}$ columns to $\mathrm{NO}_{x}$ emissions.

\section{Summary and conclusions}

In the present work, we use the satellite observations of $\mathrm{NO}_{2}$ vertical columns from the OMI instrument to quantify the summer half-year (i.e., April-September) $\mathrm{NO}_{x}$ emissions and emission trends of 35 selected US urban areas during

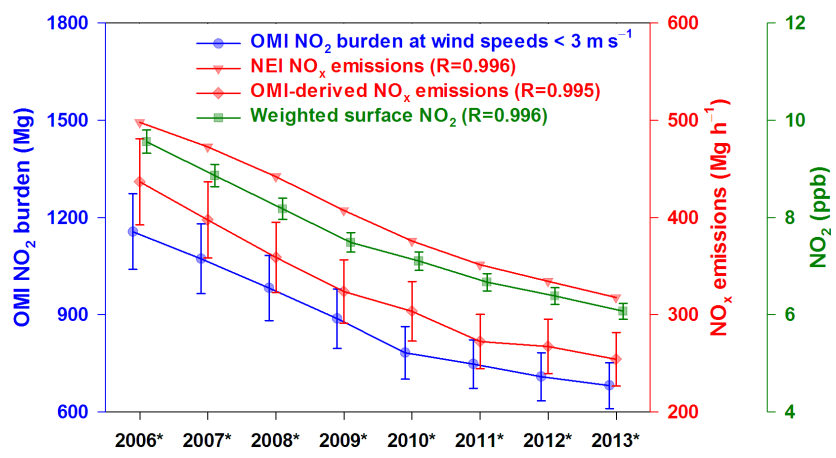

Figure 9. The 3-year moving trends of the total $\mathrm{NEI} \mathrm{NO}_{x}$ emissions, the total OMI-derived $\mathrm{NO}_{x}$ emissions, the total OMIobserved $\mathrm{NO}_{2}$ burdens under the weak-wind-speed condition, and the area-weighted average AQS surface $\mathrm{NO}_{2}$ measurements for all selected urban areas during $2006^{*}-2013 *$. Error bars express the $\pm 1 \mathrm{SD}$ of the estimates. $R$ values shown are the correlation coefficients with the OMI-observed $\mathrm{NO}_{2}$ burdens

2005-2014. To refine the analysis, we first explore the impact of winds on the satellite $\mathrm{NO}_{2}$ observations. Significant differences are found between the $\mathrm{OMI} \mathrm{NO}_{2}$ maps averaged from all valid data and those from data with slow wind speeds only, and such differences are not uniform across all urban areas but depend on local meteorological conditions. Compared to $\mathrm{NO}_{2}$ maps under all-wind conditions, the satelliteobserved $\mathrm{NO}_{2}$ signals at wind speeds $<3 \mathrm{~m} \mathrm{~s}^{-1}$ are significantly higher over the urban areas and lower in surrounding rural areas and are better correlated to the amounts of surface $\mathrm{NO}_{x}$ emissions. We observe greater $\mathrm{NO}_{2}$ column reductions over a number of selected cities from 2006* (i.e., 20052007) to 2013* (i.e., 2012-2014) under the weak-wind condition than under the all-wind condition, implying that the effect of winds should be taken into account when comparing the trends of $\mathrm{NO}_{x}$ emissions and satellite $\mathrm{NO}_{2}$ observations.

Noticing the importance of wind speed, we divide the OMI observations around each urban area into fast-wind-speed (>3 to $\left.5 \mathrm{~m} \mathrm{~s}^{-1}\right)$ and slow-wind-speed $\left(<3 \mathrm{~m} \mathrm{~s}^{-1}\right)$ groups. Daily $\mathrm{OMI} \mathrm{NO} \mathrm{N}_{2}$ data of each wind-speed group are rotated and oversampled to generate wind-aligned $\mathrm{OMI} \mathrm{NO}_{2}$ maps, the along-wind line densities of which are further fitted by an EMG function. For each urban area in any 3 consecutive years during 2005-2014, we derive the corresponding $\mathrm{NO}_{x}$ emissions and effective $\mathrm{NO}_{2}$ lifetimes from the EMG fits of the fast-wind-speed groups and the $\mathrm{OMI} \mathrm{NO}_{2}$ burdens from the slow-wind-speed groups. We find good linear agreement $(R>0.93)$ among NEI $\mathrm{NO}_{x}$ emissions, OMI-derived $\mathrm{NO}_{x}$ emissions, and $\mathrm{OMI} \mathrm{NO}_{2}$ burdens, implying the possibility of using the satellite $\mathrm{NO}_{2}$ observations under the weakwind condition to constrain the surface $\mathrm{NO}_{x}$ emissions directly. The simultaneously obtained effective $\mathrm{NO}_{2}$ lifetimes $(\sim 3.5 \pm 1.3 \mathrm{~h})$ are biased low in comparison to the summertime $\mathrm{NO}_{2}$ chemical lifetime of $\sim 7 \mathrm{~h}$, reflecting the influences 
of plume meandering and the coarse sampling resolution on the EMG-fitted results.

Finally, we quantify the $\mathrm{NO}_{x}$ reductions in selected US urban areas and compare the trends of satellite observations with those of bottom-up emissions and ground-based measurements. We find that the time series of the $\mathrm{NO}_{x}$-related quantities correlate with each other very well in most US urban areas, especially for large cities. Due to the successful control of $\mathrm{NO}_{x}$ emissions in both the power and transportation sectors, the total NEI $\mathrm{NO}_{x}$ emissions, the total OMIderived $\mathrm{NO}_{x}$ emissions, the sum of $\mathrm{OMI} \mathrm{NO}_{2}$ columns (under the weak-winds condition), the total $\mathrm{OMI} \mathrm{NO}_{2}$ burdens (under the weak-winds condition), and the average measured $\mathrm{NO}_{2}$ concentrations for all US urban areas decreased by 43 , $49,47,49$, and $44 \%$, respectively, from 2005 to 2014 . Reductions of these five $\mathrm{NO}_{x}$-related quantities were rapid, at rates of -6.8 to $-9.3 \% \mathrm{yr}^{-1}$, before 2010 and slowed down to rates of -3.4 to $-4.9 \% \mathrm{yr}^{-1}$ in recent years. Generally, the annual average rates of decrease of $\mathrm{OMI} \mathrm{NO}_{2}$ observations obtained in this work are greater than previously reported values derived from the all-wind satellite maps, further demonstrating the importance of considering winds.

We have shown that using the EMG method, the OMI has the capability to estimate $\mathrm{NO}_{x}$ emissions from urban areas directly and constrain their trends with reasonable accuracy. These OMI-derived emissions can provide independent and valuable information to policy makers and researchers in verifying the bottom-up emission estimates and inspecting the effectiveness of emission control measures, especially for areas without complete surface monitoring networks and lacking well-established emission inventories. We also show that a comprehensive and integrated analysis of satellite observations, ground measurements, and bottom-up emissions can provide a better understanding of the true $\mathrm{NO}_{x}$ situation in a given area. Furthermore, the method described in this work can be applied to the near-future satellite missions such as NASA's Tropospheric Emissions: Monitoring of Pollution (TEMPO; Chance et al., 2013) and the European Space Agency's (ESA) Tropospheric Monitoring Instrument (TROPOMI; Veefkind et al., 2012). With the improved temporal and/or spatial resolution offered by these missions, the diurnal variations of $\mathrm{NO}_{x}$ emissions and emissions from smaller sources are likely to be able to be inferred.

\section{Copyright statement}

The author's copyright for this publication is transferred to UChicago Argonne, LLC, Operator of Argonne National Laboratory.

The Supplement related to this article is available online at doi:10.5194/acp-15-10367-2015-supplement.
Acknowledgements. This work was sponsored by the National Aeronautics and Space Administration (NASA) as a part of the Air Quality Applied Sciences Team (AQAST) program, for which we are grateful to the NASA project officer John Haynes and the AQAST team leader Daniel Jacob. We acknowledge the free use of tropospheric $\mathrm{NO}_{2}$ column data from the OMI sensor available at www.temis.nl. The Argonne National Laboratory is operated by UChicago Argonne, LLC, under contract no. DE-AC02-06CH11357 with the US Department of Energy.

Edited by: N. Kramarova

\section{References}

Alvarado, M. J., Logan, J. A., Mao, J., Apel, E., Riemer, D., Blake, D., Cohen, R. C., Min, K.-E., Perring, A. E., Browne, E. C., Wooldridge, P. J., Diskin, G. S., Sachse, G. W., Fuelberg, H., Sessions, W. R., Harrigan, D. L., Huey, G., Liao, J., Case-Hanks, A., Jimenez, J. L., Cubison, M. J., Vay, S. A., Weinheimer, A. J., Knapp, D. J., Montzka, D. D., Flocke, F. M., Pollack, I. B., Wennberg, P. O., Kurten, A., Crounse, J., Clair, J. M. St., Wisthaler, A., Mikoviny, T., Yantosca, R. M., Carouge, C. C., and Le Sager, P.: Nitrogen oxides and PAN in plumes from boreal fires during ARCTAS-B and their impact on ozone: an integrated analysis of aircraft and satellite observations, Atmos. Chem. Phys., 10, 9739-9760, doi:10.5194/acp-10-9739-2010, 2010.

Bechle, M. J., Millet, D. B., and Marshall, J. D.: Remote sensing of exposure to $\mathrm{NO}_{2}$ : satellite versus ground-based measurement in a large urban, Atmos. Environ., 69, 345-353, 2013.

Beirle, S., Platt, U., von Glasow, R., Wenig, M., and Wagner, T.: Estimate of nitrogen oxide emissions from shipping by satellite remote sensing, Geophys. Res. Lett., 31, L18102, doi:10.1029/2004g1020312, 2004.

Beirle, S., Boersma, K. F., Platt, U., Lawrence, M. G., and Wagner, T.: Megacity emissions and lifetimes of nitrogen oxides probed from space, Science, 333, 1737-1739, 2011.

Beirle, S., Hörmann, C., Penning de Vries, M., Dörner, S., Kern, C., and Wagner, T.: Estimating the volcanic emission rate and atmospheric lifetime of $\mathrm{SO}_{2}$ from space: a case study for $\mathrm{Ki}$ lauea volcano, Hawai'i, Atmos. Chem. Phys., 14, 8309-8322, doi:10.5194/acp-14-8309-2014, 2014.

Boersma, K. F., Eskes, H. J., Meijer, E. W., and Kelder, H. M.: Estimates of lightning $\mathrm{NO}_{x}$ production from GOME satellite observations, Atmos. Chem. Phys., 5, 2311-2331, doi:10.5194/acp-52311-2005, 2005.

Boersma, K. F., Eskes, H. J., Veefkind, J. P., Brinksma, E. J., van der A, R. J., Sneep, M., van den Oord, G. H. J., Levelt, P. F., Stammes, P., Gleason, J. F., and Bucsela, E. J.: Near-real time retrieval of tropospheric $\mathrm{NO}_{2}$ from OMI, Atmos. Chem. Phys., 7, 2103-2118, doi:10.5194/acp-7-2103-2007, 2007.

Boersma, K. F., Eskes, H. J., Dirksen, R. J., van der A, R. J., Veefkind, J. P., Stammes, P., Huijnen, V., Kleipool, Q. L., Sneep, M., Claas, J., Leitão, J., Richter, A., Zhou, Y., and Brunner, D.: An improved tropospheric $\mathrm{NO}_{2}$ column retrieval algorithm for the Ozone Monitoring Instrument, Atmos. Meas. Tech., 4, 19051928, doi:10.5194/amt-4-1905-2011, 2011.

Carn, S. A., Krotkov, N. A., Yang, K., and Krueger, A. J.: Measuring global volcanic degassing with the Ozone Monitoring Instru- 
ment (OMI), in: Remote Sensing of Volcanoes and Volcanic Processes: Integrating Observation and Modeling, edited by: Pyle, D. M., Mather, T. A., and Biggs, J., Geological Society, Special Publications, 380, London, 229-257, 2013.

Chance, K., Liu, X., Suleiman, R. M., Flittner, D. E., Al-Saadi, J., and Janz, S. J.: Tropospheric emissions: monitoring of pollution (TEMPO), in: Proc. SPIE 8866, Earth Observing Systems XVIII, San Diego, California, USA, 25 August 2013, doi:10.1117/12.2024479, 2013.

Dallmann, T. R. and Harley, R. A.: Evaluation of mobile source emission trends in the United States, J. Geophys. Res., 115, D14305, doi:10.1029/2010jd013862, 2010.

de Foy, B., Krotkov, N. A., Bei, N., Herndon, S. C., Huey, L. G., Martínez, A.-P., Ruiz-Suárez, L. G., Wood, E. C., Zavala, M., and Molina, L. T.: Hit from both sides: tracking industrial and volcanic plumes in Mexico City with surface measurements and $\mathrm{OMI} \mathrm{SO}_{2}$ retrievals during the MILAGRO field campaign, Atmos. Chem. Phys., 9, 9599-9617, doi:10.5194/acp-9-9599-2009, 2009.

de Foy, B., Wilkins, J. L., Lu, Z., Streets, D. G., and Duncan, B. N.: Model evaluation of methods for estimating surface emissions and chemical lifetimes from satellite data, Atmos. Environ., 98, 66-77, 2014.

de Foy, B., Lu, Z., Streets, D. G., Lamsal, L. N., and Duncan, B. N.: Estimates of power plant $\mathrm{NO}_{x}$ emissions and lifetimes from $\mathrm{OMI} \mathrm{NO}_{2}$ satellite retrievals, Atmos. Environ., 116, 1-11, 2015.

Dee, D. P., Uppala, S. M., Simmons, A. J., Berrisford, P., Poli, P., Kobayashi, S., Andrae, U., Balmaseda, M. A., Balsamo, G., Bauer, P., Bechtold, P., Beljaars, A. C. M., van de Berg, L., Bidlot, J., Bormann, N., Delsol, C., Dragani, R., Fuentes, M., Geer, A. J., Haimberger, L., Healy, S. B., Hersbach, H., Holm, E. V., Isaksen, L., Kallberg, P., Kohler, M., Matricardi, M., McNally, A. P., Monge-Sanz, B. M., Morcrette, J. J., Park, B. K., Peubey, C., de Rosnay, P., Tavolato, C., Thepaut, J. N., and Vitart, F.: The ERA-Interim reanalysis: configuration and performance of the data assimilation system, Q. J. Roy. Meteor. Soc., 137, 553-597, 2011.

Demerjian, K. L.: A review of national monitoring networks in North America, Atmos. Environ., 34, 1861-1884, 2000.

Dommen, J., Prevot, A. S. H., Hering, A. M., Staffelbach, T., Kok, G. L., and Schillawski, R. D.: Photochemical production and aging of an urban air mass, J. Geophys. Res., 104, 5493-5506, 1999.

Duncan, B. N., Yoshida, Y., de Foy, B., Lamsal, L. N., Streets, D. G., Lu, Z., Pickering, K. E., and Krotkov, N. A.: The observed response of Ozone Monitoring Instrument (OMI) $\mathrm{NO}_{2}$ columns to $\mathrm{NO}_{x}$ emission controls on power plants in the United States: 2005-2011, Atmos. Environ., 81, 102-111, 2013.

Fioletov, V. E., McLinden, C. A., Krotkov, N., Moran, M. D., and Yang, K.: Estimation of $\mathrm{SO}_{2}$ emissions using OMI retrievals, Geophys. Res. Lett., 38, L21811, doi:10.1029/2011g1049402, 2011.

Fioletov, V. E., McLinden, C. A., Krotkov, N., Yang, K., Loyola, D. G., Valks, P., Theys, N., Van Roozendael, M., Nowlan, C. R., Chance, K., Liu, X., Lee, C., and Martin, R. V.: Application of OMI, SCIAMACHY, and GOME-2 satellite $\mathrm{SO}_{2}$ retrievals for detection of large emission sources, J. Geophys. Res., 118, 11399-11418, 2013.
Fioletov, V. E., McLinden, C. A., Krotkov, N., and Li, C.: Lifetimes and emissions of $\mathrm{SO}_{2}$ from point sources estimated from OMI, Geophys. Res. Lett., 42, 1969-1976, 2015.

Hilboll, A., Richter, A., and Burrows, J. P.: Long-term changes of tropospheric $\mathrm{NO}_{2}$ over megacities derived from multiple satellite instruments, Atmos. Chem. Phys., 13, 4145-4169, doi:10.5194/acp-13-4145-2013, 2013.

Hudman, R. C., Russell, A. R., Valin, L. C., and Cohen, R. C.: Interannual variability in soil nitric oxide emissions over the United States as viewed from space, Atmos. Chem. Phys., 10, 9943 9952, doi:10.5194/acp-10-9943-2010, 2010.

Ialongo, I., Hakkarainen, J., Hyttinen, N., Jalkanen, J.-P., Johansson, L., Boersma, K. F., Krotkov, N., and Tamminen, J.: Characterization of OMI tropospheric $\mathrm{NO}_{2}$ over the Baltic Sea region, Atmos. Chem. Phys., 14, 7795-7805, doi:10.5194/acp-14-77952014, 2014.

Jaeglé, L., Steinberger, L., Martin, R. V., and Chance, K.: Global partitioning of $\mathrm{NO}_{x}$ sources using satellite observations: relative roles of fossil fuel combustion, biomass burning and soil emissions, Faraday Discuss., 130, 407-423, 2005.

Kalambet, Y., Kozmin, Y., Mikhailova, K., Nagaev, I., and Tikhonov, P.: Reconstruction of chromatographic peaks using the exponentially modified Gaussian function, J. Chemometr., 25, 352-356, 2011.

Kim, S. W., Heckel, A., McKeen, S. A., Frost, G. J., Hsie, E. Y., Trainer, M. K., Richter, A., Burrows, J. P., Peckham, S. E., and Grell, G. A.: Satellite-observed US power plant $\mathrm{NO}_{x}$ emission reductions and their impact on air quality, Geophys. Res. Lett., 33, L22812, doi:10.1029/2006g1027749, 2006.

Kim, S. W., Heckel, A., Frost, G. J., Richter, A., Gleason, J., Burrows, J. P., McKeen, S., Hsie, E. Y., Granier, C., and Trainer M.: $\mathrm{NO}_{2}$ columns in the western United States observed from space and simulated by a regional chemistry model and their implications for $\mathrm{NO}_{x}$ emissions, J. Geophys. Res., 114, D11301, doi:10.1029/2008jd011343, 2009.

Krotkov, N. A., Schoeberl, M. R., Morris, G. A., Carn, S., and Yang, K.: Dispersion and lifetime of the $\mathrm{SO}_{2}$ cloud from the August 2008 Kasatochi eruption, J. Geophys. Res., 115, D00120, doi:10.1029/2010jd013984, 2010.

Kunhikrishnan, T., Lawrence, M. G., von Kuhlmann, R., Richter, A., Ladstatter-Weissenmayer, A., and Burrows, J. P.: Analysis of tropospheric $\mathrm{NO}_{x}$ over Asia using the model of atmospheric transport and chemistry (MATCH-MPIC) and GOME-satellite observations, Atmos. Environ., 38, 581-596, 2004.

Lamsal, L. N., Martin, R. V., van Donkelaar, A., Celarier, E. A., Bucsela, E. J., Boersma, K. F., Dirksen, R., Luo, C., and Wang, Y.: Indirect validation of tropospheric nitrogen dioxide retrieved from the OMI satellite instrument: insight into the seasonal variation of nitrogen oxides at northern midlatitudes, J. Geophys. Res., 115, D05302, doi:10.1029/2009jd013351, 2010.

Lamsal, L. N., Martin, R. V., Padmanabhan, A., van Donkelaar, A., Zhang, Q., Sioris, C. E., Chance, K., Kurosu, T. P., and Newchurch, M. J.: Application of satellite observations for timely updates to global anthropogenic $\mathrm{NO}_{x}$ emission inventories, Geophys. Res. Lett., 38, L05810, doi:10.1029/2010g1046476, 2011.

Lamsal, L. N., Duncan, B. N., Yoshida, Y., Krotkov, N. A., Pickering, K. E., Streets, D. G., and Lu, Z.: US $\mathrm{NO}_{2}$ trends (20052013): EPA Air Quality System (AQS) data versus improved 
observations from the Ozone Monitoring Instrument (OMI), Atmos. Environ., 110, 130-143, 2015.

Leue, C., Wenig, M., Wagner, T., Klimm, O., Platt, U., and Jahne, B.: Quantitative analysis of $\mathrm{NO}_{x}$ emissions from Global Ozone Monitoring Experiment satellite image sequences, J. Geophys. Res., 106, 5493-5505, 2001.

Levelt, P. F., Van den Oord, G. H. J., Dobber, M. R., Malkki, A., Visser, H., de Vries, J., Stammes, P., Lundell, J. O. V., and Saari, H.: The Ozone Monitoring Instrument, IEEE T. Geosci. Remote, 44, 1093-1101, 2006.

Lu, Z., and Streets, D. G.: Increase in $\mathrm{NO}_{x}$ emissions from Indian thermal power plants during 1996-2010: unit-based inventories and multisatellite observations, Environ. Sci. Technol., 46, 74637470, 2012.

Lu, Z., Streets, D. G., de Foy, B., and Krotkov, N. A.: Ozone Monitoring Instrument observations of interannual increases in $\mathrm{SO}_{2}$ emissions from Indian coal-fired power plants during 20052012, Environ. Sci. Technol., 47, 13993-14000, 2013.

Martin, R. V.: Satellite remote sensing of surface air quality, Atmos. Environ., 42, 7823-7843, 2008.

Martin, R. V., Jacob, D. J., Chance, K., Kurosu, T. P., Palmer, P. I., and Evans, M. J.: Global inventory of nitrogen oxide emissions constrained by space-based observations of $\mathrm{NO}_{2}$ columns, J. Geophys. Res., 108, D174537, doi:10.1029/2003jd003453, 2003.

McDonald, B. C., Dallmann, T. R., Martin, E. W., and Harley, R. A.: Long-term trends in nitrogen oxide emissions from motor vehicles at national, state, and air basin scales, J. Geophys. Res., 117, D00v18, doi:10.1029/2012jd018304, 2012.

Mebust, A. K., Russell, A. R., Hudman, R. C., Valin, L. C., and Cohen, R. C.: Characterization of wildfire $\mathrm{NO}_{x}$ emissions using MODIS fire radiative power and OMI tropospheric $\mathrm{NO}_{2}$ columns, Atmos. Chem. Phys., 11, 5839-5851, doi:10.5194/acp11-5839-2011, 2011.

Nunnermacker, L. J., Imre, D., Daum, P. H., Kleinman, L., Lee, Y. N., Lee, J. H., Springston, S. R., Newman, L., Weinstein-Lloyd, J., Luke, W. T., Banta, R., Alvarez, R., Senff, C., Sillman, S., Holdren, M., Keigley, G. W., and Zhou, X.: Characterization of the Nashville urban plume on July 3 and July 18, 1995, J. Geophys. Res., 103, 28129-28148, 1998.

Nunnermacker, L. J., Kleinman, L. I., Imre, D., Daum, P. H., Lee, Y. N., Lee, J. H., Springston, S. R., Newman, L., and Gillani, N.: $\mathrm{NO}_{y}$ lifetimes and $\mathrm{O}_{3}$ production efficiencies in urban and power plant plumes: analysis of field data, J. Geophys. Res., 105, 91659176, 2000.

Richter, A., Burrows, J. P., Nuss, H., Granier, C., and Niemeier, U.: Increase in tropospheric nitrogen dioxide over China observed from space, Nature, 437, 129-132, 2005.

Russell, A. R., Valin, L. C., Bucsela, E. J., Wenig, M. O., and Cohen, R. C.: Space-based constraints on spatial and temporal patterns of $\mathrm{NO}_{x}$ emissions in California, 2005-2008, Environ. Sci. Technol., 44, 3608-3615, 2010.

Russell, A. R., Valin, L. C., and Cohen, R. C.: Trends in $\mathrm{OMI} \mathrm{NO}_{2}$ observations over the United States: effects of emission control technology and the economic recession, Atmos. Chem. Phys., 12, 12197-12209, doi:10.5194/acp-12-12197-2012, 2012.

Schneider, P., Lahoz, W. A., and van der A, R.: Recent satellitebased trends of tropospheric nitrogen dioxide over large ur- ban agglomerations worldwide, Atmos. Chem. Phys., 15, 12051220, doi:10.5194/acp-15-1205-2015, 2015.

Sillman, S.: Ozone production efficiency and loss of $\mathrm{NO}_{x}$ in power plant plumes: photochemical model and interpretation of measurements in Tennessee, J. Geophys. Res., 105, 9189-9202, 2000.

Spicer, C. W.: Nitrogen-oxide reactions in the urban plume of Boston, Science, 215, 1095-1097, 1982.

Streets, D. G., Canty, T., Carmichael, G. R., de Foy, B., Dickerson, R. R., Duncan, B. N., Edwards, D. P., Haynes, J. A., Henze, D. K., Houyoux, M. R., Jacobi, D. J., Krotkov, N. A., Lamsal, L. N., Liu, Y., Lu, Z., Martini, R. V., Pfister, G. G., Pinder, R. W., Salawitch, R. J., and Wechti, K. J.: Emissions estimation from satellite retrievals: a review of current capability, Atmos. Environ., 77, 1011-1042, 2013.

Streets, D. G., de Foy, B., Duncan, B. N., Lamsal, L. N., Li, C., and Lu, Z.: Using satellite observations to measure power plant emissions and their trends, EM Magazine, 64, 16-21, 2014.

Theys, N., Campion, R., Clarisse, L., Brenot, H., van Gent, J., Dils, B., Corradini, S., Merucci, L., Coheur, P.-F., Van Roozendael, M., Hurtmans, D., Clerbaux, C., Tait, S., and Ferrucci, F.: Volcanic $\mathrm{SO}_{2}$ fluxes derived from satellite data: a survey using OMI, GOME-2, IASI and MODIS, Atmos. Chem. Phys., 13, 59455968, doi:10.5194/acp-13-5945-2013, 2013.

Tong, D. Q., Lamsal, L. N., Pan, L., Ding, C., Kim, H., Lee, P., Chai, T., Pickering, K. E., and Stajner, I.: Long-term $\mathrm{NO}_{x}$ trends over large cities in the United States during the Great Recession: comparison of satellite retrievals, ground observations, and emissioninventories, Atmos. Environ., 107, 70-84, 2015.

US EPA: Evaluating the uncertainty of emission estimates, in: Emission Inventory Improvement Program Technical Report Series Volume VI, Quality assurance procedures and DARS software Chapter 4, 55 pp., Research Triangle Park, North Carolina, USA, 1996.

Valin, L. C., Russell, A. R., and Cohen, R. C.: Variations of OH radical in an urban plume inferred from $\mathrm{NO}_{2}$ column measurements, Geophys. Res. Lett., 40, 1856-1860, 2013.

van $\operatorname{der}$ A, R. J., Eskes, H. J., Boersma, K. F., van Noije, T. P. C., Van Roozendael, M., De Smedt, I., Peters, D. H. M. U., and Meijer, E. W.: Trends, seasonal variability and dominant $\mathrm{NO}_{x}$ source derived from a ten year record of $\mathrm{NO}_{2}$ measured from space, J. Geophys. Res., 113, D04302, doi:10.1029/2007jd009021, 2008.

Veefkind, J. P., Aben, I., McMullan, K., Forster, H., de Vries, J., Otter, G., Claas, J., Eskes, H. J., de Haan, J. F., Kleipool, Q., van Weele, M., Hasekamp, O., Hoogeveen, R., Landgraf, J., Snel, R., Tol, P., Ingmann, P., Voors, R., Kruizinga, B., Vink, R., Visser, H., and Levelt, P. F.: TROPOMI on the ESA Sentinel-5 Precursor: a GMES mission for global observations of the atmospheric composition for climate, air quality and ozone layer applications, Remote Sens. Environ., 120, 70-83, 2012.

Wang, S. W., Streets, D. G., Zhang, Q. A., He, K. B., Chen, D., Kang, S. C., Lu, Z., and Wang, Y. X.: Satellite detection and model verification of $\mathrm{NO}_{x}$ emissions from power plants in Northern China, Environ. Res. Lett., 5, 044007, doi:10.1088/17489326/5/4/044007, 2010.

Wang, S. W., Zhang, Q., Streets, D. G., He, K. B., Martin, R. V., Lamsal, L. N., Chen, D., Lei, Y., and Lu, Z.: Growth in $\mathrm{NO}_{x}$ emissions from power plants in China: bottom-up estimates 
and satellite observations, Atmos. Chem. Phys., 12, 4429-4447, doi:10.5194/acp-12-4429-2012, 2012.

Xing, J., Pleim, J., Mathur, R., Pouliot, G., Hogrefe, C., Gan, C.-M., and Wei, C.: Historical gaseous and primary aerosol emissions in the United States from 1990 to 2010, Atmos. Chem. Phys., 13, 7531-7549, doi:10.5194/acp-13-7531-2013, 2013.
Zhang, Q., Streets, D. G., and He, K. B.: Satellite observations of recent power plant construction in Inner Mongolia, China, Geophys. Res. Lett., 36, L15809, doi:10.1029/2009g1038984, 2009. 